\title{
EL TRABAJO FORZADO, LA SERVIDUMBRE Y LA ESCLAVITUD EN EUROPA ATENDIENDO A LOS SECTORES PRODUCTIVOS: ANÁLISIS CRÍTICO DEL ALCANCE DE LA JURISPRUDENCIA DEL ARTÍCULO 4 DEL CONVENIO EUROPEO DE DERECHOS HUMANOS*
}

\author{
FORCED LABOUR, SERVITUDE AND SLAVERY IN EUROPE ACCORDING TO THE \\ PRODUCTIVE SECTORS: CRITICAL ANALYSIS OF THE SCOPE OF THE CASE LAW \\ OF ARTICLE 4 OF THE EUROPEAN CONVENTION ON HUMAN RIGHTS
}

\author{
Borja Fernández Burgueño**
}

\begin{abstract}
RESUMEN: Este trabajo analiza el desarrollo y alcance de la jurisprudencia del Tribunal Europeo de Derechos Humanos en torno al artículo 4 del Convenio Europeo de Derechos Humanos de acuerdo con los tres sectores económicos: primario, secundario y terciario. Siguiendo el método hipotético-deductivo, se discuten las siguientes dos cuestiones: (1) "el alcance efectivo del artículo 4 del CEDH varía considerablemente en cada sector económico sin que exista correlación entre el nivel de desarrollo de la jurisprudencia del TEDH y los sectores en los que hay más víctimas de trabajo forzado u obligatorio, servidumbre y esclavitud" y (2) "el reducido número de casos en relación con el artículo 4 del CEDH ha impedido al TEDH determinar el alcance efectivo de sus disposiciones". Este trabajo concluye corroborando la veracidad de la primera de las premisas y matizando la segunda.
\end{abstract}

\begin{abstract}
This paper analyses the developments and scope of the case-law of the European Court of Human Rights on article 4 of the European Convention on Human Rights according to the three economic sectors: primary, secondary and tertiary. Based on the hypothetico-deductive model, the following two questions are discussed: (1) "the effective scope of article 4 of the ECHR varies significantly between each economic sector with no correlation between the level of development of the case-law and the number of victims of forced or compulsory labour, servitude and slavery in each sector" and (2) "the small number of cases relating to article 4 of the ECHR has barred the ECtHR from determining the effective scope of its terms". This article concludes by proving the accuracy of the former premise and qualifying the latter.
\end{abstract}

PALABRAS ClAVE: trabajo forzado, servidumbre, esclavitud, sector económico, sector productivo, CEDH.

KEY WORDS: forced labour, servitude, slavery, economic sector, productive sector, ECHR.

Fecha de recepción: 11/11/2016

Fecha de aceptación: 23/12/2016

doi: https://doi.org/10.20318/universitas.2017.3558

\footnotetext{
* Artículo supervisado por el Prof. Dr. Fernández de Casadevante de la Universidad Rey Juan Carlos.

** Estudiante de posgrado del Máster de Acceso a la Profesión de Abogado en la Universidad Autónoma de Madrid y del Máster de Derechos Humanos de la UNED. Email: borja.fernandezb@estudiante.uam.es / bfernande774@alumno.uned.es
} 


\section{1.- INTRODUCCIÓN}

\section{1.- Objeto del estudio}

Si bien la esclavitud y el trabajo forzado son prácticas formalmente abolidas, siguen aún presentes en nuestra sociedad en múltiples formas y afectan a una gran variedad de sectores económicos. De acuerdo con la Asamblea Parlamentaria del Consejo de Europa, estas prácticas afectan a la industria sexual, al sector agrario, a la construcción, a la industria textil, al sector hotelero, a la restauración, al empleo doméstico y a la mendicidad forzada, entre otros ámbitos ${ }^{1}$.

Desgraciadamente, la esclavitud y el trabajo forzado no son asuntos del pasado, ni siquiera en Europa. De hecho, varios Estados del Consejo de Europa (CdE) miembros del Convenio Europeo para la protección de los Derechos Humanos y de las Libertades Fundamentales (CEDH) ya han sido condenados por el Tribunal Europeo de Derechos Humanos (TEDH) por violar el artículo 4 del CEDH ${ }^{2}$. Además, los Estados parte del CEDH no solo son culpables de no haberse enfrentado con éxito a la esclavitud y al trabajo forzado en su jurisdicción ${ }^{3}$, sino de consentir y beneficiarse de un sistema económico que, con el único objetivo de reducir los costes de producción, ha externalizado también la explotación laboral a terceros países a través de la deslocalización de su industria.

La Organización Internacional del Trabajo (OIT) cifra en 20,9 millones las víctimas de trabajos forzosos y esclavitud ${ }^{4}$. De estas personas, el $90 \%$ (18,7 millones) son víctimas de explotación por parte de empresas o particulares y el $10 \%$ restante por los Estados. Los trabajos forzosos generan enormes beneficios para las empresas y particulares implicados. Se calcula que las ganancias alcanzan los 150.000 millones de dólares anuales ${ }^{5}$. De acuerdo con la división regional que utiliza la OIT $^{6}$, las víctimas de trabajos forzados se distribuyen de la siguiente manera: 11.700 .000 en Asia-Pacífico, 3.700.000 en África,

\footnotetext{
${ }^{1}$ COUNCIL OF EUROPE, Parliamentary Assembly resolution 1922 (2013). Párr. 2.

${ }^{2}$ Rantsev C. Chipre y Rusia, no. 25965/04. [TEDH, Sección I], 7 de enero de 2010; Siliadin c. Francia, no. 73316/01. [TEDH, Sección II], 26 de julio de 2005; C.N. y V. c. Francia, no. 67724/09. [TEDH, Sección V], 11 de octubre de 2012; C.N. C. Reino Unido, no. 4239/08. [TEDH, Sección IV], 13 de noviembre de 2012; Chitos c. Grecia, no. 51637/12. [TEDH, Sección I] 04 de junio de 2015; L.E. C. Grecia, no. 71545/12. [TEDH, Sección I], 21 de enero de 2016.

${ }^{3}$ Nótese que, aunque el artículo 1 del CEDH limita el alcance del CEDH a la jurisdicción de los Estados Parte, la protección efectiva de los Derechos Humanos puede tener un alcance extraterritorial. Soering c. Reino Unido, no. 14038/88. [TEDH, Plenario] 7 de julio de 1989 Párr. 89-87; Chahal c. Reino Unido, no. 22414/93. [TEDH, Gran Sala] 15 de noviembre de 1996; D. C. Reino Unido, no. 30240/96 [TEDH, Sala], 2 de mayo de 1997.

${ }^{4}$ INTERNATIONAL LABOUR OFFICE (ILO): Profits and Poverty: The Economics of Forced Labour. ILO publications: Geneva, 2014. P.7.

${ }^{5}$ Ibídem.

6 Nótese que los países parte del CEDH se encuentran divididos en dos grupos: los Estados no comunitarios del Este de Europa y la CIE y las economías desarrolladas y la UE.
} 
1.800.000 en Latinoamérica y el Caribe, 1.600 .000 en los Estados no comunitarios del Este de Europa y de la CIE (Comunidad de Estados Independientes), 1.500 .000 en las economías desarrolladas y en la UE y 600.000 en Oriente Medio.

En la UE y en las economías desarrolladas, la esclavitud, la servidumbre y el trabajo forzado son un negocio con una altísima rentabilidad. Mientras que la OIT cifra en 1,5 millones ( $7 \%$ del total) las víctimas de estas prácticas en la UE y en las economías desarrolladas, los ingresos se elevan hasta los 46.900 millones de dólares $\left(31 \%\right.$ del total) ${ }^{7}$, lo que se traduce en $34.800 \$$ por persona, frente a los $5.000 \$$ por víctima en Asia y en la Región Pacífica o los $3.900 \$$ en África ${ }^{8}$. Asimismo, en los Estados no comunitarios del Este de Europa y de la CIE, la OIT estima que las 1.600 .000 de víctimas de trabajos forzados $(7.65 \%$ del total) generan un beneficio total de 18 millones de dólares (12\% del total) 0 $12.900 €$ anuales por víctima.

Tal y como Mantouvalou señala, algunos derechos laborales, incluido el núcleo del derecho a no ser sometido a esclavitud, servidumbre o trabajo forzado, son, a su vez, derechos humanos ${ }^{9}$. Sin embargo, esta naturaleza no aparta la prohibición del ámbito laboral, sino que reafirma su necesaria presencia en el espacio empresarial y en el derecho del trabajo en su conjunto. Mantouvalou afirma que "si la ley [laboral] se queda corta en [la] protección [de los derechos humanos], la respuesta ha de ser que la ley debe cambiar" ${ }^{\prime 10}$. Por su parte, Davidov apunta a una justificación kantiana del derecho laboral basada en el concepto de la dignidad y los derechos humanos ${ }^{11}$. En este sentido, en el caso de que los derechos humanos cayeran en el olvido en el ámbito laboral, se correría el riesgo de que el hombre dejara de ser un fin en sí mismo para convertirse en un mero medio productivo, poniendo en peligro su propia dignidad ${ }^{12}$.

Las disposiciones del Convenio Europeo para la protección de los Derechos Humanos y de las Libertades Fundamentales (CEDH) regulan, tanto de forma directa como indirecta, una gran cantidad de aspectos relativos a las relaciones laborales ${ }^{13}$, entre los que cabe destacar: la

\footnotetext{
7 INTERNATIONAL LABOUR OFFICE (ILO): Profits and Poverty: The Economics of Forced Labour. ILO publications: Geneva, 2014. P. 13.

${ }^{8}$ Ibídem. P. 14.

9 MANTOUVALOU, V.: "Are Labour Rights Human Rights?". UCL On-Line Working Papers. LRI WP X/2012. 2012. P. 22 (traducción).

${ }^{10}$ Ibídem. P. 27 (traducción propia del inglés).

${ }^{11}$ DAVIDOV, G.: A Purposive Approach to Labour Law. OUP: Oxford. 2016. Pp. 61-62.

12 Hay que destacar que, a diferencia de la Carta de los Derechos Fundamentales de la Unión Europea (CDFUE), el concepto de dignidad no aparece explícitamente recogido en el CEDH. Véase un análisis de la relación entre el concepto de la dignidad y los Derechos Humanos en FERNÁNDEZ BURGUEÑO, B. "The uselfulness of the legal concept of dignity in the human rights discourse: literature review". Oxímora: revista internacional de ética y política. no. 8, 2016.

13 DORSSEMONT, F; LORCHER, K; SCHOMANN, I.: The European Convention on Human Rights and the Employment Relation. A\&C Black: London, 2014; ECHR, Factsheet Work-related rights. Enero 2016. Accedido el 01 de mayo de 2016. Disponible online en: http://www.echr.coe.int/Documents/FS Work ENG.pdf
} 
prohibición de la esclavitud, la servidumbre y el trabajo forzado (art. 4 CEDH), el derecho a un juicio laboral justo (art. $6 \mathrm{CEDH})^{14}$, la privacidad en el entorno laboral (art. $8 \mathrm{CEDH})^{15}$, la libertad de expresión en el lugar de trabajo (art. $10 \mathrm{CEDH})^{16}$, la libertad de reunión y de asociación en la empresa (art. 11) ${ }^{17}$ y la prohibición de la discriminación laboral (art.14 $\mathrm{CEDH})^{18}$.

Este trabajo se centrará en el artículo 4 del CEDH: la disposición que de forma más clara define los límites últimos de las relaciones laborales. El contenido de la prohibición del artículo 4 del CEDH está, por su naturaleza, íntimamente ligado al sector empresarial y a las relaciones entre el empleado y el empleador. En este sentido, el TEDH ha señalado que "el artículo 4 exige a los Estados miembros que pongan en vigor medidas que regulen los negocios" para evitar que las empresas sometan a sus empleados a trabajos forzados, servidumbre o esclavitud ${ }^{19}$. Esta última apreciación por la que se vincula la actividad empresarial con el artículo 4 del CEDH cobra especial relevancia a la luz del último informe de 2016 de la Comisión Europea sobre la Trata de seres humanos, una de las principales manifestaciones del trabajo forzado y la servidumbre en Europa, en el que se subraya que "a pesar de que la actividad empresarial pueda tanto perpetuar la trata de seres humanos como contribuir a erradicarlo, la mayoría de las empresas no son conscientes de los vínculos [de sus actividades con estas prácticas]"20.

\section{2.- Estado de la cuestión}

De 1959 a 2015, el TEDH ha fallado 6 veces $^{21}$ que un Estado miembro ha vulnerado el artículo 4 del $\mathrm{CEDH}$, a lo que hay que añadir el reciente caso L.E. v. Grecia de 21 de enero de 2016. No obstante, la cifra palidece al compararla con las 15.570 ocasiones en las que el TEDH ha emitido sentencia condenatoria, representando apenas un $0,04 \%$ del

\footnotetext{
${ }^{14}$ Ver ej: Lombardi Vallauri c. Italia, no. 39128/05. [TEDH, Sección II], 20 de octubre de 2009; Vilho Eskelinen y Otros c. Finlandia, no. 63235/00. [TEDH, Gran Sala], 19 de abril de 2007.

${ }^{15}$ Ver ej: Halford c. Reino Unido. no. 20605/92. [TEDH, Sala], 25 de junio de 1997

${ }^{16}$ Ver ej: Alexandridis c. Grecia, no. 19516/06. [TEDH; Sala], 21 de febrero de 2008; Larissis y Others C. Grecia, no. 140/1996/759/958-960. [TEDH; Sala], 24 de febrero de 1998.

17 Ver ej: Wilson, and the National Union of Journalists, Palmer, Wyeth and the National Union of Rail Maritime and Transport Workers and Doolan y Otros c. Reino Unido. nos. 30668/96, 30671/96 and 30678/96. [TEDH, Sección II], 02 de julio de 2002; Demir y Beykara c. Turquía, no. 34503/97. [TEDH, Gran Sala], 12 de noviembre de 2008.

${ }^{18}$ Ver ej: Thlimmenos c. Grecia, no 34369/97. [TEDH, Gran Sala], 6 de abril de 2000.

${ }^{19}$ Rantsev c. Chipre y Rusia, no. 25965/04. [TEDH, Sección I], 7 de enero de 2010, párr. 284.

20 COMMISSION TO THE EUROPEAN PARLIAMENT AND THE COUNCIL. Report on the progress made in the fight against trafficking in human beings (2016). Brussels, 19.5.2016 $\operatorname{COM}(2016) 267$ final, P. 11.

${ }^{21}$ Las estadísticas del TEDH computan el caso Rantsev c. Chipre y Rusia, por dos al estar involucrados tanto Rusia como Chipre.
} 
total $^{22}$. En contraste, el TEDH ha fallado que la prohibición de trato inhumano o degradante ha sido vulnerada un total de 1.670 veces $(10,72 \%)$, el derecho a la libertad y a la seguridad en 3.053 ocasiones $(19,6 \%)$, el derecho a un juicio justo 4.329 veces $(27,8 \%)$ y el derecho a un procedimiento sin dilaciones indebidas 5.435 veces $(34,9 \%)^{23}$.

El hecho de que las cifras de vulneración del artículo $4 \mathrm{CEDH}$ sean considerablemente inferiores a las de otros artículos no significa necesariamente que el nivel de protección efectiva sea superior al de los demás derechos del CEDH, sobre todo al recordar que la OIT cifra en 1,5 millones las víctimas de trabajos forzados en la UE y en las economías desarrolladas ${ }^{24}$ y que el número de asuntos pendientes ante el TEDH supera los 64.800 casos $^{25}$. Asimismo, en la Resolución 1922, la Asamblea Parlamentaria del CdE reconoció que "se cree que todos los países están virtualmente afectados, ya sea como países de origen, tránsito o destino"26. El reducido número de casos fundados que han llegado al TEDH se puede deber a varias causas, entre las que destaco: las limitaciones de acceso de las víctimas de la explotación a la justicia en general y al TEDH en particular, el hecho de que de la interpol estime que tan sólo entre un $5 \%$ y un $10 \%$ de estos casos llegan al conocimiento de las autoridades y en una proporción todavía menor las víctimas sean identificadas ${ }^{27}$, la falsa creencia de que la esclavitud y el trabajo forzado son asuntos ya superados en Europa y el desconocimiento del potencial alcance del artículo 4 del $\mathrm{CEDH}^{28}$.

22 ECHR: Violations by Article and respondent State 1959-2015. ECHR Statistical Reports: Ginebra. Accedido el 02 de mayo de 2016. Online en: http://www.echr.coe.int/Documents/Stats violation_1959 2015 ENG.pdf

${ }^{23}$ Ibídem.

${ }^{24}$ La OIT clasifica a algunos Estados parte del CEDH como Rusia y el resto de los países europeos del este no comunitarios dentro del Estados no comunitarios del Este de Europa y de la CIE. Este conjunto de estados sería responsable, de acuerdo con la OIT, de 1,6 millones de víctimas de esclavitud y trabajos forzosos. International Labour Office (ILO): Profits and Poverty: The Economics of Forced Labour. ILO publications: Geneva, 2014. P.7

${ }^{25}$ ECHR. Analysis of statistics 2015. ECHR Statistical Reports: Ginebra. P. 4. Accedido el 02 de mayo de 2016. Disponible online en: http://www.echr.coe.int/Documents/Stats analysis 2015 ENG.pdf

${ }^{26}$ COUNCIL OF EUROPE, Parliamentary Assembly resolution 1922 (2013). Párr. 1.

27 COUNCIL OF EUROPE, Parliamentary Assembly resolution 1922 (2013)iError! Marcador no definido.. Párr. 3.

28 El alcance efectivo de algunos artículos del CEDH había sido menospreciado hasta hace relativamente poco tiempo. Por ejemplo, el alcance del artículo 4 del protocolo 4 del CEDH sobre la prohibición de las expulsiones colectivas de extranjeros era desconocido hasta el caso Čonka v. Belgium (no. 51564/99, TEDH, 5 de febrero de 2002) y su aplicación fue exitosamente explorada a partir del caso Hirsi Jamaa y Otros c. Italia. (no. 27765/09, TEDH, 23 de febrero de 2012). Este artículo pasó de ser ignorado al epicentro de la cuestión de la legalidad de la política europea de frontera, especialmente tras el acuerdo con Turquía, y de la gestión española de sus fronteras con Ceuta y Melilla (ver caso el caso pendiente: D. y N.T. C. España (decisión), no. 8675/15 y 8697/15. [TEDH, Sección III], 07 de julio de 2015). 
El análisis sobre el alcance del artículo 4 del CEDH cobra especial relevancia cuando países como Francia ${ }^{29}$, al que España debe gran parte de su ordenamiento jurídico; Grecia ${ }^{30}$, al que Europa debe el origen de su cultura; o Reino Unido ${ }^{31}$, uno de los impulsores del CEDH y el corazón económico de Europa, han sido condenados por el TEDH, en al menos una ocasión, por haber vulnerado sus términos.

\section{3.- Hipótesis a contrastar y estructura del artículo}

Siguiendo el método hipotético-deductivo, este artículo partirá de las siguientes dos hipótesis:

1. "El alcance efectivo del artículo 4 del CEDH varía considerablemente en cada sector económico sin que exista correlación entre el nivel de desarrollo de la jurisprudencia del TEDH y los sectores en los que hay más víctimas de trabajo forzado u obligatorio, servidumbre y esclavitud".

2. "El reducido número de casos en relación con el artículo 4 del CEDH ha impedido al TEDH determinar el alcance efectivo de sus disposiciones".

Con el fin de comprobar la veracidad de estas dos premisas, este artículo se divide en tres secciones. En la primera se estudiará el alcance de la prohibición del trabajo forzado, la servidumbre y la esclavitud en el derecho internacional y en el CEDH. En la segunda sección se examinará la jurisprudencia del TEDH desde el punto de vista de la producción de bienes y la prestación de servicios. Para ello, se clasificarán los casos atendiendo a los tres sectores de la producción: sector primario, secundario y terciario. Para terminar, se analizarán los resultados obtenidos del análisis de la jurisprudencia del TEDH por sectores económicos contrastándolos con las dos hipótesis iniciales.

\section{2.- LA PROHIBICIÓN DE LA ESCLAVITUD, LA SERVIDUMBRE Y EL TRABAJO FORZADO}

En esta sección situará la prohibición de la esclavitud, la servidumbre y el trabajo forzado en el marco del derecho internacional, estudiando su presencia en tratados internacionales, en el derecho consuetudinario, su carácter como norma perentoria $y$, finalmente su redacción en el artículo 4 del CEDH.

\footnotetext{
${ }^{29}$ Siliadin c. Francia, no. 73316/01. [TEDH, Sección II], 26 de julio de 2005; C.N. y V. c. Francia, no. 67724/09. [TEDH, Sección V], 11 de octubre de 2012.

30 Chitos c. Grecia, no. 51637/12. [TEDH], 04 de junio de 2015; L.E. V. Grecia, no. 71545/12. [TEDH], 21 de enero de 2016.

${ }^{31}$ C.N. c. Reino Unido, no. 4239/08. [TEDH, Sección IV], 13 de noviembre de 2012.
} 


\section{1.- La esclavitud, la servidumbre y el trabajo forzado en el derecho internacional consuetudinario y su carácter de norma perentoria}

La prohibición de la esclavitud y del trabajo forzado está recogida en numerosos tratados internacionales de derechos humanos ${ }^{32} \mathrm{y}$, tal como señala Sieghart, forma parte del derecho internacional consuetudinario $^{33}$. No obstante, el carácter de norma ius cogens de la prohibición de la esclavitud y la servidumbre y del trabajo forzado u obligatorio merece un análisis separado.

Por un lado, la mayor parte de la doctrina afirma que el núcleo de la prohibición de la esclavitud y la servidumbre constituye una norma perentoria de derecho internacional ${ }^{34}$. En este sentido, Shawn, apoyándose en el carácter absoluto de la prohibición de la esclavitud y de la servidumbre, que se ve reflejado tanto en el CEDH (art. 15§2) como el Pacto Internacional de Derechos Civiles y Políticos (art.4§2), afirma que el hecho de que varios tratados internacionales establezcan que la prohibición no pueda ser derogada, constituye una evidencia de que dicha disposición alcanza el umbral de norma imperativa de derecho internacional ${ }^{35}$. Sin embargo, Mantouvalou señala que la universalidad de la prohibición y el consenso sobre su alcance se difuminan a medida que nos alejamos su núcleo ${ }^{36}$.

Por otro lado, el carácter de norma perentoria de la prohibición del trabajo forzado u obligatorio es considerablemente más difuso que el de la esclavitud y la servidumbre. La OIT sostuvo en un informe de 1998

32 Convenio de la OIT no. 29 relativo al trabajo forzoso u obligatorio (1930, Entrada en vigor: 01 mayo 1932); art. 4 Declaración Universal de los Derechos Humanos (1948); Convenio relativo a la abolición del trabajo forzoso (1957, Entrada en vigor: 17 enero 1959); art. 8 Pacto Internacional de Derechos Civiles y Políticos (1966, Entrada en vigor: 23 de marzo de 1976); art. 6 Convención Americana sobre Derechos Humanos (1969, Entrada en vigor: 18 de julio de 1978.); art. 5 Carta Africana sobre los Derechos Humanos y de los Pueblos (1981, Entrada en vigor: 21 de octubre de 1986); art. 4 CEDH; art. 5 Carta de los Derechos Fundamentales de la Unión Europea (2000, Entrada en vigor del Tratado de Lisboa: 1 de diciembre de 2009); Protocolo de 2014 relativo al Convenio sobre el trabajo forzoso (2014, Entrará en vigor: 09 noviembre 2016). Asimismo, la esclavitud, en todas sus formas, está prohibida bajo el derecho humanitario consuetudinario tanto en conflictos internacionales como no internacionales. Ver HENACKAERTS, JM; y DOSWALD-BECK, L. "Rule 94. Slavery and the slave trade in all their forms are prohibited". en INTERNATIONAL COMMITTEE OF THE RED CROSS. Customary International Humanitarian Law. Volume 1. Rules. CUP: New York 2009. P. 327.

33 SIEGHART, P. The international Law of Human Rights. OUP Oxford 1983, pp. 54-5. Citado en WHITE, R. \& OVEY, C. The European Convention on Human Rights. $5^{\circ}$ ed. OUP: Oxford 2010, P. 196.

34 SHAWN, M.N.: International Law. $6^{\circ}$ Ed. CUP: Cambridge 2008, P. 275; ALLAIN, J. Slavery in International Law: of Human Exploitation and Trafficking. Brill: Nijhoff 2012, P. 254.

${ }^{35}$ SHAWN, M.N.: International Law. $6^{\circ}$ Ed. CUP: Cambridge 2008, P. 275

36 MANTOUVALOU, V.: "Are Labour Rights Human Rights?". UCL On-Line Working Papers. LRI WP X/2012. 2012. P. 22. 
sobre el trabajo forzado en Birmania que "actualmente existe en derecho internacional una norma perentoria que prohíbe cualquier recurso del uso del trabajo forzado y el derecho a no ser constreñido a realizar trabajo forzado u obligatorio es uno de los derechos humanos básicos" ${ }^{37}$. Sin embargo, parte de la doctrina no comparte las conclusiones de la OIT. Así, Allain alega que la prohibición perentoria del trabajo forzado solo abarca circunstancias en las que el trabajo forzado ocurre contra la voluntad de la persona, se realiza bajo la amenaza de una sanción y está vinculado a derechos ligados a la propiedad sobre la persona, es decir, cuando se trata de esclavitud ${ }^{38}$.

Por tanto, podemos concluir que, si bien la prohibición de la esclavitud y la servidumbre alcanza el carácter de norma perentoria, la prohibición del trabajo forzado u obligatorio aún no ha alcanzado tal nivel.

\section{2.- La esclavitud, la servidumbre y el trabajo forzado en el CEDH}

El Convenio Europeo de Derechos Humanos recoge la prohibición de la esclavitud, la servidumbre y el trabajo forzado en su artículo 4 . De acuerdo con la clasificación de Ripol Carulla, citada por Fernández de Casadevante, que a su vez sigue el criterio de Réné Cassin, la prohibición de la esclavitud y del trabajo forzado forma parte de los "derechos que se reconocen al individuo en tanto que persona" ${ }^{\prime 39}$. El artículo 4 del $\mathrm{CEDH}$ establece que:

1. Nadie podrá ser sometido a esclavitud o servidumbre.

2. Nadie podrá ser constreñido a realizar un trabajo forzado u obligatorio.

3. No se considera como "trabajo forzado u obligatorio" en el sentido del presente artículo:

a) todo trabajo exigido normalmente a una persona privada de libertad en las condiciones previstas por el artículo 5 del presente Convenio, o durante su libertad condicional;

37 ILO. Forced labour in Myanmar (Burma). Report of the Commission of Inquiry appointed under article 26 of the Constitution of the International Labour Organization to examine the observance by Myanmar of the Forced Labour Convention, 1930 (No. 29) Geneva, 2 July 1998. Accedido el 1 de mayo de 2016. Párr. 203 (traducción). Disponible online

http://www.ilo.org/public/english/standards/relm/gb/docs/gb273/myanmar3.htm.

Citado en SAUL, B.; KINLEY, D.; MOWBRAY, J.: The International Covenant on Economic, Social and Cultural Rights: Commentary, Cases, and Materials. OUP: Oxford, 2014. P. 346. También citado en ALLAIN, J. Slavery in International Law: of Human Exploitation and Trafficking. Brill: Nijhoff 2012, P. 248.

38 ALLAIN, J. Slavery in International Law: of Human Exploitation and Trafficking. Brill: Nijhoff , 2012, P. 254.

39 RIPOL CARULLA, SA.: "El sistema europeo de protección internacional de los Derechos Humanos y el Derecho Español" en RIPOL CARULLA, SA (Dir.). España en Estrasburgo. Tres décadas bajo la Jurisdicción del Tribunal Europeo de Derechos Humanos, Thomson Reuters: Cizur Menor, 2010, citado en FERNÁNDEZ DE CASADEVANTE ROMANI, C.: "EI sistema europeo: El Consejo de Europa y los Derechos Individuales (I)" en FERNÁNDEZ DE CASADEVANTE ROMANI, C. (Dir.), et. al: Derecho Internacional de los Derechos Humanos. $4^{\circ}$ Ed. Dilex: Madrid, 2013. P. 190 
b) todo servicio de carácter militar o, en el caso de objetores de conciencia en los países en que la objeción de conciencia sea reconocida como legítima, cualquier otro servicio sustitutivo del servicio militar obligatorio;

c) todo servicio exigido cuando alguna emergencia o calamidad amenacen la vida o el bienestar de la comunidad;

d) todo trabajo o servicio que forme parte de las obligaciones cívicas normales.

White y Ovey ponen de relieve la particularidad de la estructura del artículo $4 \mathrm{CEDH}$ afirmando que "ninguna otra prohibición sustancial de la Convención está redactada de esta manera"40. El artículo 4 está dividido en tres apartados. Los dos primeros establecen las prohibiciones sustanciales, mientras que el tercero se limita a señalar una lista de situaciones en las que no habrá de entenderse vulnerada la prohibición del apartado segundo. El apartado segundo y tercero han de ser leídos de forma conjunta ya que, como señala Castillo Daudí, "el párrafo 2 forma con [el párrafo 3] una unidad, contribuyendo a su interpretación" ${ }^{41}$. El TEDH ha señalado en repetidas ocasiones que, a pesar de la diversidad de las circunstancias del apartado tercero, todas "están basadas en las ideas gobernantes del interés general, la solidaridad social y el curso normal de las cosas" ${ }^{\prime 2}$.

Otra característica particular del artículo $4 \mathrm{CEDH}$ es su relación con el artículo 15§2, relativo a los artículos absolutos sobre los que no cabe excepción alguna, ni siquiera en situación de emergencia que amenace la vida de la nación ${ }^{43}$. A diferencia del resto de los artículos a los que el artículo $15 \S 2$ otorga el carácter de absolutos, sólo el apartado primero del artículo $4 \mathrm{CEDH}$ (prohibición de someter a esclavitud o servidumbre) no puede ser derogado, mientras que cabe derogación de los apartados segundo y tercero (prohibición de constreñir a realizar un trabajo forzado u obligatorio) en tiempos de guerra o emergencia pública. Atendiendo a la clasificación de los derechos del CEDH que White, Ovey, Banketas, y Oete formulan, el apartado $4 \S 1$ se encuentra dentro de los derechos "unqualified" -ya que el CEDH no permite que se pondere con otros

\footnotetext{
${ }^{40}$ WHITE, R. \& OVEY, C. The European Convention on Human Rights. OUP: Oxford 2010 $5^{\circ}$ ed, p. 195 (traducción propia del inglés).

${ }^{41}$ CASTILLO DAUDÍ, M. Derecho Internacional de los Derechos Humanos. 20 Edición. Tirant lo Blanch: Valencia, 2006. P. 127.

42 Ver: Van der Mussele C. Bélgica, no. 8919/80. [TEDH, Plenario], 23 de noviembre de 1983, parr. 38; Graziani-Weiss c. Austria, no. 31950/06. [TEDH, Sección II], 18 de octubre de 2011, párr. 37; Zarb Adami c. Malta, no. 17209/02. [TEDH, Sección IV], 20 de junio de 2006; párr. 44; Karlheinz Schmidt c. Alemania, no. 13580/88. [TEDH, Sala], 18 de julio de 1994, párr. 22; Stummer c. Austria, no. 37452/02. [TEDH, Gran Sala], 07 de julio de 2011, párr. 120; Mihal c. Eslovaquia (decisión), no. [TEDH, Sección III], 28 de junio de 2011, párr. 43; Meier c. Suiza, no. 10109/14. [TEDH, Sección III], 9 de febrero de 2016, párr. 65; Graziani-Weiss c. Austria, no. 31950/06. [TEDH, Sección II], 18 de octubre de 2011, párr. 37.

${ }^{43}$ Ver: Siliadin c. Francia, no. 73316/01. [TEDH] 26 de julio de 2005, párr. 112; Rantsev c. Chipre y Rusia, no. 25965/04. [TEDH, Sección I], 7 de enero de 2010, párr. 283.
} 
intereses nacionales ${ }^{44}$ - y absolutos -puesto que no cabe derogación alguna en virtud del artículo $15 \mathrm{CEDH-;} \mathrm{mientras} \mathrm{que} \mathrm{el} 4 \S 2$ es un derecho "unqualified", pero no-absoluto ${ }^{45}$.

\section{3.- ANÁLISIS DEL ARTÍCULO 4 CEDH POR SECTORES ECONÓMICOS}

De acuerdo con Mantouvalou, hay que distinguir entre el núcleo abstracto de la prohibición de la esclavitud, servidumbre y trabajado forzado y sus requisitos concretos adicionales ${ }^{46}$. Según esta autora, a diferencia del núcleo de la prohibición, no todos los requisitos específicos han de ser considerados derechos humanos, sino "estándares laborales"47. Asimismo, Mantouvalou señala que mientras que el núcleo tiene un carácter atemporal, los requisitos específicos pueden variar con el tiempo y dependen inevitablemente del sistema de producción $n^{48}$. Esta reflexión guiará la estructura de esta sección del artículo en dos sentidos. Primero, el carácter temporal del alcance de la prohibición puesto en relación con la doctrina del "instrumento vivo" del TEDH, invita a reflejar la interpretación del CEDH a la luz de circunstancias actuales. Por tanto, cada sección procurará no solo recoger las principales sentencias y casos pendientes del TEDH, sino también proyectar el alcance de la jurisprudencia a nuestros días. Segundo, las diferencias orgánicas de cada sistema de producción hacen necesario analizar la jurisprudencia del TEDH atendiendo a los sectores productivos. En este sentido, con el fin de adecuar la estructura del artículo al ámbito de la Administración y Dirección de Empresa y poder contrastar las dos hipótesis iniciales, esta sección estará estructurada de acuerdo con la clasificación tradicional planteada por Fisher $^{49}$ y Clark $^{50}$ de los sectores económicos: sector primario, secundario y terciario ${ }^{51}$.

${ }^{44}$ Comparar con los artículos $8 \S 2,9 \S 2,10 \S 2$ y $11 \S 2$ del CEDH y el art. $1 \S 2$ del Protocolo adicional Primero y los apartados 3 y 4 del art. 2 del Protocolo Adicional Segundo.

${ }^{45}$ WHITE, R. \& OVEY, C. The European Convention on Human Rights. OUP: Oxford 2010 50 ed, P. 8; BANKETAS, I; y OETE, L. International Human Rights Law and Practice. CUP: New York 2013. P. 223.

${ }^{46}$ MANTOUVALOu, V.: "Are Labour Rights Human Rights?". UCL On-Line Working Papers. LRI WP X/2012. 2012. P. 22.

${ }^{47}$ Ibídem.

48 Ibídem.

${ }^{49}$ FISHER, A. G. "Production, primary, secondary and tertiary". Economic Record, v. 15, n. 1, 1933, pp.24-38. Citado en QUINET DE ANDRADE BASTOS, S; y SALGUEIRO PEROBELLI, F. "The search of homogeneity in the heterogeneity: An analysis of the service sector in Brazil". Offshore services in Global Value Chains: New drivers of structural change in Latin America and the Caribbean? REDLAS, Conference paper: Chile, 2012.

${ }^{50}$ CLARK, C. A. The Conditions of Economic Progress. Londres: Macmilan, 1940 citado en QUINET DE ANDRADE BASTOS, S; y SALGUEIRO PEROBELLI, F.: "The search of homogeneity in the heterogeneity: An analysis of the service sector in Brazil". Offshore services in Global Value Chains: New drivers of structural change in Latin America and the Caribbean?, REDLAS, Conference paper: Chile, 2012.P. 1.

${ }^{51}$ Algunos autores dividen el sector terciario en dos, dando lugar a un cuarto sector. En este sentido ver: KENESSEY, Z.: "The primary, secondary, tertiary and quaternary 


\section{1.- Sector primario}

Griffiths y Wall definen el sector primario como "aquellas actividades directamente relacionadas con los recursos naturales, como, por ejemplo, la agricultura, la minería y la extracción de petróleo" ${ }^{\prime 52}$. El sector primario es la base del sistema productivo sobre la que se apoyan los demás sectores económicos. El sector primario agrupa todas las actividades económicas destinadas a la extracción de bienes de la naturaleza que posteriormente son tratados o transformados (sector secundario) y que, finalmente, son objeto de servicios (sector terciario).

Según los datos de la OIT, las víctimas forzadas a trabajar en la agricultura, silvicultura y pesca ${ }^{53}$ alcanzan un total de 530.000 personas en las economías desarrolladas y en la UE y 470.000 en los Estados no comunitarios del Este de Europa y de la $\mathrm{CIE}$, generando unos beneficios anuales de 6.400 millones de dólares (12.200\$ por víctima) y 700 millones de dólares (1.400\$ por víctima), respectivamente ${ }^{54}$. Estas cifras apuntan a un problema de dimensiones mayúsculas que, de ser ciertas, no solo viciarían las bases del sistema productivo, sino que supondría un duro golpe para las democracias de los Estados miembros del CEDH ya que, como ha repetido el TEDH en numerosas ocasiones, la prohibición de la esclavitud, la servidumbre y el trabajo forzado constituye uno de los pilares fundamentales de la democracia ${ }^{55}$ y su vulneración es incompatible con los valores democráticos del CEDH ${ }^{56}$.

La magnitud del número de víctimas de trabajos forzados en el sector primario y su elevada cifra de beneficios anuales, evidencian la inadecuada gestión de los Estados miembros del CEDH para poner fin a esta lacra. Ante esta situación, resulta alarmante que, hasta la fecha, el TEDH no haya encontrado a ningún solo Estado parte del CEDH culpable de haber vulnerado el artículo 4 del CEDH, ni tan siquiera en sus obligaciones positivas de investigar y prevenir activamente estas prácticas. De hecho, sin perjuicio de que algún caso no haya sido cubierto por esta investigación, la única sentencia que se ha encontrado en la que se analiza sustancialmente el artículo 4 del CEDH en relación con trabajos forzados en el sector primario ha sido el caso acumulado de De Wilde,

sectors of the economy". Review of Income and Wealth. Volume 33, Issue 4, 1987. Pp. 359-385.

52 GRIFFITHS, A; y WALL, S.: Applied Economics. Twelfth Edition, Financial Times Press: UK, 2011. P. 2 (traducción propia del inglés).

${ }^{53}$ La OIT no incluye la minería en la clasificación.

54 International Labour Office (ILO): Profits and Poverty: The Economics of Forced Labour. ILO publications: Geneva, 2014. Pp. 18,22.

55 Siliadin C. Francia, no. 73316/01. [TEDH] 26 de julio de 2005, párr. 112, 121, 148; Stummer c. Austria, no. 37452/02. [TEDH, Gran Sala], 07 de julio de 2011, párr. 116; C.N. y V. c. Francia, no. 67724/09. [TEDH, Sección V], 11 de octubre de 2012. Párr. 68 ${ }^{56}$ Rantsev C. Chipre y Rusia, no. 25965/04. [TEDH, Sección I], 07 de enero de 2010, párr. 282. 
Ooms y Versyp c. Bélgica ${ }^{57}$ (también conocido como el caso del vagabundeo o "vagrancy case"), en concreto el caso de Versyp ${ }^{58}$.

Versyp era una persona sin recursos a la que las autoridades belgas detuvieron en un "centro de vagabundos"59. Para poder ser liberado del centro, necesitaba acumular un total de 2.000 francos belgas ${ }^{60}$. Para conseguir tal cantidad, se le requirió trabajar en un campo de patatas ${ }^{61}$ pagándole tan solo 1,75 francos belgas por hora ${ }^{62}$. A la hora de valorar una posible violación del artículo 4 del CEDH, el TEDH comenzó subrayando que -en el apartado anterior- había concluido que Grecia había violado del artículo $5 \S 4$ del $\mathrm{CEDH}^{63}$ en la medida en que los demandantes no tuvieron acceso a un recurso efectivo sobre la legalidad de su detención ${ }^{64}$. No obstante, el TEDH estimó que no había habido violación el artículo $4 \S 2$ en relación con el $4 \S 3 . a)^{65}$ porque los vagabundos fueron legalmente detenidos bajos el artículo 5§1.e). Como bien puntualizan White y Ovey:

"Esta es una decisión perpleja ya que el artículo ha de ser leído en su conjunto, y parece que cualquier violación de los párrafos (1)-(4) convertirían el arresto o detención ilegal. No es suficiente con decir que la detención estaba justificada bajo una disposición del Convenio si a su vez es ilícita bajo otra disposición. Ni tampoco el artículo 4(3)(a) diferencia entre las disposiciones del artículo 5."66

Con base en la anterior interpretación desacertada de la relación entre el artículo 5 y el artículo 4§3.a), el TEDH concluyó que, puesto que el trabajo se encontraba "dentro de los límites de lo 'normal', (...) estaba dirigido a la rehabilitación del detenido y se basaba en estándares generales (...) equivalentes a los de varios estados miembros, (...) las

${ }^{57}$ De Wilde, Ooms y Versyp c. Bélgica, no. 2832/66, 2835/66, 2899/66. [TEDH, Pleno], 18 de junio de 1971.

58 El caso de Versyp es en el único en el que aparecen elementos suficientes en el apartado "As to the facts" (párr. 13 a 43) que indican que en el demandante realizó trabajos relacionados con el sector primario ("potato picking", párr. 31). En la descripción de los hechos del caso De Wilde no se describen los trabajos que se le requirieron y en el caso de Oooms sólo podemos deducir que tenía que realizar "trabajos pesados" ("heavy work", párr. 27). De Wilde, Ooms y Versyp c. Bélgica, no. 2832/66, 2835/66, 2899/66. [TEDH, Pleno], 18 de junio de 1971.

${ }^{59}$ Ibídem párr. 29.

${ }^{60}$ Ibídem párr. 32.

${ }^{61}$ Ibídem párr. 31.

62 Ibídem párr. 32.

${ }^{63}$ Art. $5 \S 4$ del CEDH: "Toda persona privada de su libertad mediante arresto o detención tendrá derecho a presentar un recurso ante un órgano judicial, a fin de que se pronuncie en breve plazo sobre la legalidad de su detención y ordene su puesta en libertad si dicha detención fuera ilegal."

${ }^{64}$ De Wilde, Ooms y Versyp c. Bélgica, no. 2832/66, 2835/66, 2899/66. [TEDH, Pleno], 18 de junio de 1971 . Párr. 80.

${ }^{65}$ Art. $4 \S 3$ del CEDH: "No se considera como "trabajo forzado u obligatorio" en el sentido del presente artículo: a) todo trabajo exigido normalmente a una persona privada de libertad en las condiciones previstas por el artículo 5 del presente Convenio, o durante su libertad condicional".

${ }^{66}$ WHITE, R. \& OVEY, C. The European Convention on Human Rights. OUP: Oxford 2010 $5^{\circ}$ ed, P. 202 (traducción propia del inglés). 
autoridades belgas no habían por tanto vulnerado los requisitos del artículo $4^{\prime \prime 67}$.

Conviene hacer una pequeña reseña a la sentencia sobre el procedimiento $^{68}$ anterior a la sentencia sobre el fondo del asunto $D e$ Wilde, Ooms y Versyp c. Bélgica, en la que se estudia las modalidades de acceso al TEDH. El asunto procesal trató sobre si el abogado de los demandantes podía defender el caso frente al TEDH en vez de hacerlo la Comisión Europea de los Derechos Humanos (aunque supervisado por esta), ya que, por aquel entonces, de acuerdo con el antiguo artículo 44 del $C_{E D H}{ }^{69}$, sólo tenían acceso al Tribunal los Estados miembros ${ }^{70}$ y la Comisión. Los abogados de las víctimas solo podían actuar en calidad de asistentes si la Comisión así lo solicitaba. En una decisión controvertida, el TEDH lo permitió. El juez ROLIN, en su voto particular concurrente, juzgó adecuado que la Comisión recurriera a asistentes, pero consideró inaceptable que el abogado se dirigiera al tribunal "en el nombre de la Comisión"71. Por su parte, el juez FAVRE alegó que la sentencia "no era compatible con el [antiguo] artículo 44 del CEDH [y que] se alejaba de la práctica establecida"72. Afortunadamente, este debate ha perdido vigencia con la entrada en vigor del protocolo número 11 del CEDH en 1998. Actualmente el artículo 34 del CEDH permite a cualquier persona física, organización no gubernamental o grupo de particulares que se considere víctima de una violación, presentar una demanda individual directamente ante del TEDH. Esta enmienda al CEDH supone uno de los mayores avances en materia de protección de los derechos humanos. La posibilidad de realizar demandas individuales resulta especialmente relevante en relación con el artículo 4 del CEDH no solo porque elimina el procedimiento ante la Comisión Europea de los Derechos Humanos ${ }^{73}$, facilitando el acceso al TEDH a las víctimas de la esclavitud, la servidumbre y el trabajo forzado, sino porque ninguna de las demandas inter-estatales en la historia del CEDH ha tratado sobre el artículo 4.

Haciendo uso de dicha potestad de presentar una demanda individual directamente ante del TEDH, el 27 de abril de 2015, cuarenta y dos bangladeshíes invocaron el artículo 4 del CEDH contra Grecia por no haber asumido su obligación positiva de investigar una red de trata de seres humanos, adoptar medidas preventivas y sancionar a sus culpables.

${ }^{67}$ Ibídem párr. 89-90 (traducción propia del inglés).

68 De Wilde, Ooms y Versyp c. Bélgica (Cuestiones de Procedimiento), no. 2832/66, 2835/66, 2899/66. [TEDH, Pleno], 18 de noviembre de 1970.

69 Antiguo artículo 44 : «Seules les Hautes Parties Contractantes et la Commission ont qualité pour se présenter devant la Cour »

70 Ver, inter alia: Irlanda c. Reino Unido, no. 5310/71. [TEDH, Pleno], 18 de enero de 1978.

${ }^{71}$ De Wilde, Ooms y Versyp c. Bélgica (Cuestiones de Procedimiento), no. 2832/66, 2835/66, 2899/66. [TEDH, Pleno], 18 de noviembre de 1970 (ROLIN, H. concurring).

72 De Wilde, Ooms y Versyp c. Bélgica (Cuestiones de Procedimiento), no. 2832/66, 2835/66, 2899/66. [TEDH, Pleno], 18 de noviembre de 1970 (FAVRE, A. dissenting) (traducción propia del inglés).

73 La Comisión Europea de Derechos Humanos dejó de existir cuando el TEDH devino permanente el 1 de noviembre de 1998 con la entrada en vigor del Protocolo número 11. 
El caso Chowdury y Otros c. Grecia ${ }^{74}$, que está actualmente pendiente de resolución, podría marcar el comienzo de un nuevo ciclo en la protección de las víctimas de trabajos forzados del sector primario.

De acuerdo con los hechos que se exponen en la comunicación del caso Chowdury ${ }^{75}$, los cuarenta y dos demandantes, todos ellos inmigrantes de Bangladesh sin permiso de trabajo, fueron reclutados en Atenas entre octubre de 2012 y febrero de 2013 para trabajar en una explotación de fresas en Manolada, Grecia, bajo la promesa de un salario de $22 €$ por 7 horas de trabajo. Mientras vivían en refugios improvisados de cartón, nylon y bambú en los que "no había ni baños ni agua corriente y hacía tanto calor que la piel se fundía"76, trabajaban de 7 a 7 bajo la mirada de hombres armados. A pesar de la insistencia de los trabajadores, los empleadores se negaron a pagarles y, en abril de 2013, ordenaron traer una nueva tanda de inmigrantes. Ante esta situación y bajo el temor de que nunca iban a cobrar, un grupo de trabajadores increparon a uno de los empleadores presentes, quién, como respuesta, desenfundó su arma de fuego e hirió gravemente a treinta de ellos. Dos días más tarde, los dos empleadores fueron arrestados. A todo esto, la policía estaba informada del hecho de que los trabajadores no recibían salario alguno, pero no contactó con la unidad de inspección laboral, no informó a los trabadores de sus derechos y tampoco abrió una investigación por trata de seres humanos. Por su parte, la justicia desestimó las querellas contra los acusados por el delito de trata, juzgando que los querellantes podían dejar el trabajo en cualquier momento y que no estaban en una situación de suficiente vulnerabilidad.

A la hora de resolver este caso, el TEDH deberá determinar si los cuarenta y dos demandantes fueron constreñidos a realizar un trabajo forzado, pudiendo concluir que solo parte de ellos lo fueron ${ }^{77}$. Para ello, deberá analizar si el trabajo se realizó en contra de su voluntad y bajo la amenaza de una sanción ${ }^{78}$. Una interpretación correcta del concepto de sanción, no solo habrá de tener en cuenta el hecho de que el trabajo se ejecutase bajo la supervisión de hombres armados, sino también su situación de vulnerabilidad en tanto que inmigrantes irregulares y el temor a su expulsión a Bangladesh ${ }^{79}$. De ser alcanzada la conclusión de

${ }^{74}$ Chowdury y Otros c. Grecia. (Caso Comunicado), n. 21884/15. [TEDH, Sección I] 09 de septiembre de 2015.

75 Ibidem. «Les circonstances de l'espèce»

76 Tribunal de lo Penal de Patra, citado en Chowdury y Otros c. Grecia. Demanda, n. 21884/15. [TEDH] 09 de septiembre de 2015. «Les circonstances de l'espèce» (traducción propia del francés).

77 Por ejemplo, en el caso C.N. y V. c. Francia (no. 67724/09. [TEDH, Sección V], 11 de octubre de 2012), sólo una de las dos demandantes fue considerada que había sido expuesta a trabajos forzados.

${ }^{78}$ Ver requisitos del trabajo forzado en: Van der Mussele c. Bélgica, no. 8919/80. [TEDH, Plenario], 23 de noviembre de 1983; C.N. y V. c. Francia, no. 67724/09. [TEDH, Sección V], 11 de octubre de 2012. Párr. 71.

${ }^{79}$ EI TEDH ha interpretado que el concepto de sanción abarca el temor a ser expulsado del país en C.N. y V. C. Francia, no. 67724/09. [TEDH, Sección V], 11 de octubre de 2012. Párr. 78. 
que fueron sometidos a trabajo forzado, el TEDH deberá examinar si las autoridades griegas investigaron adecuadamente la situación y adoptaron las medidas apropiadas para proteger a las víctimas, teniendo en cuenta que esta obligación no puede imponer una carga desproporcionada a los Estados $^{80}$. La actuación reactiva de las autoridades policiales griegas, a pesar de tener conocimiento de los hechos, podría motivar una vulneración de sus obligaciones positivas bajo el artículo 4 del CEDH. Finalmente, el TEDH deberá valorar si Grecia contaba con una legislación disuasoria y que adoptó las medidas necesarias para penar de manera suficiente a los responsables del trato contrario al artículo 4 del $\mathrm{CEDH}$, siendo esta obligación una cuestión de medios no de fines ${ }^{81}$. El hecho de que la conducta de los empleadores no fuera calificada como trata bajo la legislación griega será determinante.

A pesar de que los hechos del caso Chowdury se remontan a más de tres años atrás, la sentencia que emita el TEDH tendrá una gran repercusión en la actualidad. En 2015, las llegadas de inmigrantes y refugiados a las costas griegas se incrementaron exponencialmente, pasando de 1.694 llegadas en el mes de enero a las 211.663 tan solo en octubre $^{82}$. El ACNUR cifra en 856.723 las personas que llegaron a las costas helenas en 2015, a lo que hay que añadir las 155.300 llegadas en lo que va de año (hasta mayo de 2016) ${ }^{83}$. De acuerdo con la opinión del sector doctrinal mayoritario, la política de cierre de fronteras de la UE y la ausencia de vías legales y seguras para acceder al territorio europeo han desplazado de facto el control del flujo migratorio a manos de las mafias $^{84}$. Este traspaso del control del flujo migratorio a contrabandistas

${ }^{80}$ Para un análisis del alcance de la obligación positiva de investigar ver: Osman c. Reino Unido, no. 23452/94 [TEDH, Grand Chamber], 28 de octubre de 1998; ver también: L.E. c. Grecia, no. 71545/12. [TEDH, Sección I], 21 de enero de 2016. Párr. 67.

${ }^{81}$ Por ejemplo, el TEDH concluyó que tanto Francia como el Reino Unido no tenían una legislación a la altura de sus obligaciones positivas bajo el artículo 4 del CEDH. Ver: Siliadin c. Francia, no. 73316/01. [TEDH, Sección II], 26 de julio de 2005, párr. 130149; C.N. C. Reino Unido, no. 4239/08. [TEDH, Sección IV], 13 de noviembre de 2012, párr. 76.

82 UNITED NATIONS HIGH COMMISSIONER FOR THE REFUGEES. Greece data snapshot 05 May 2016. UNHCR Data Portal - Greece. Actualizado el 05 de mayo de 2016. Accedido el 08 de mayo de 2016.

${ }^{83}$ Ibídem.

84 Ver: CRÉPEAU, F. "Confianza en la movilidad a través de más de una generación". Revista Migraciones Forzadas. Oxford Refugee Studies Centre, University of Oxford. P.4; COSTELLO, C: "No tiene que por qué ser así". Revista Migraciones Forzadas n. 51, 2016. Oxford Refugee Studies Centre, University of Oxford. P.12-14; BREEN, D. "Abusos en las fronteras". Revista Migraciones Forzadas n. 51, 2016. Oxford Refugee Studies Centre, University of Oxford. P.4.; KARAGATSOS, K. "El punto de vista de un oficial de la guardia costera: reforzar la migración a través de los canales legales". Revista Migraciones Forzadas n. 51, 2016. Oxford Refugee Studies Centre, University of Oxford. P.47; STAVROPOULOU, M. "La protección para los refugiados en Europa: ¿Es hora de una gran reforma?" Revista Migraciones Forzadas n. 51, 2016. Oxford Refugee Studies Centre, University of Oxford. P.7-9; HERNÁN DEL VALLE; BEN ALI, R; y TURNER, W. "Búsqueda y salvamento en el Mediterráneo central". Revista Migraciones Forzadas n. 51, 2016. Oxford Refugee Studies Centre, University of Oxford. P.25-26; BANK, 
no solo ha convertido el Mediterráneo en un cementerio ${ }^{85}$, sino que ha puesto a los inmigrantes, muchos de ellos refugiados en necesidad de protección internacional, en una situación de especial vulnerabilidad frente a las redes de trata, muchas de ellas seguramente con una estructura organizativa y poder coercitivo mayores que la del caso Chowdury. De hecho, en un reciente informe conjunto de la Interpol y la Europol, se estimó el $90 \%$ de las llegas de inmigrantes a Europa había sido facilitado en su mayoría por organizaciones criminales ${ }^{86}$. En conclusión, la decisión del TEDH sobre las obligaciones positivas de Grecia en lo que respecta a la investigación de redes de trata $y$, en especial, a la obligación de adoptar medidas preventivas para evitar la explotación de personas en el sector primario será, sin duda, de una importante repercusión no solo en Grecia sino en el resto de los países parte del CEDH a la luz de los flujos migratorios actuales.

Para terminar, cabe señalar que la OIT afirma que el mayor problema del trabajo forzoso en el sector primario en la UE radica en la explotación de trabajadores inmigrantes en los empleos estacionarios ${ }^{87}$. La contratación estacionaria de inmigrantes en pésimas condiciones es un problema que afecta particularmente a España en relación con los jornaleros magrebíes en los campos de Andalucía o los trabajadores subsaharianos en labores de pesca en el norte de España. La Agencia de la UE sobre los Derechos Fundamentales (FRA), en un informe de 2015, puso de relieve que España es uno de los países de la UE con más explotación laboral y señaló que las autoridades españolas tienen una gran dificultad para enfrentarse a las organizaciones criminales internacionales responsables de la explotación de inmigrantes ${ }^{88}$. Por tanto, cabe esperar que la sentencia Chowdury y Otros c. Grecia tenga también una importante repercusión en relación con la situación de los inmigrantes trabajadores estacionales en el sector primario español.

R. "Access to protection and the limitations on extraterritorial border control: the case of refugees at sea" en Public Seminar Series, Seminar recorded on 27 February 2013 at the Oxford Department of International Development, University of Oxford. https://podcasts.ox.ac.uk/access-protection-and-limitations-extraterritorialborder-control-case-refugees-sea.

85 De acuerdo con los guardacostas helenos, 272 personas fallecieron y 152 desaparecieron en 2015 en las costas griegas. Desde el 1 de enero al 5 de mayo de 2016, 138 personas han fallecido y 24 han desaparecido. UNITED NATIONS HIGH COMMISSIONER FOR THE REFUGEES. Greece data snapshot - 05 May 2016. UNHCR Data Portal - Greece. Actualizado el 05 de mayo de 2016. Accedido el 08 de mayo de 2016.

86 EUROPOL-INTERPOL. Migrant Smuggling Networks, Joint Europol-Interpol Report. Executive Summary, May 2016, P. 6. Accedido el 19 de mayo de 2016.

87 INTERNATIONAL LABOUR OFFICE (ILO): Profits and Poverty: The Economics of Forced Labour. ILO publications: Geneva, 2014. P.19

88 EUROPEAN UNION AGENCY FOR FUNDAMENTAL RIGHTS: Severe labour exploitation: workers moving within or into the European Union States' obligations and victims' rights. Italia, 2015. P. 89 Disponible online en: http://fra.europa.eu/sites/default/files/fra-2015severe-labour-exploitation en.pdf 


\section{2.- Sector Secundario}

El sector secundario agrupa "toda la producción de bienes, incluido el tratamiento de los materiales producidos en el sector primario"89. Esta clasificación incluye, la construcción, la manufactura, el sector textil y la fabricación de maquinaria, entre otras industrias.

La OIT calcula que hay más de 7 millones personas víctimas de trabajos forzados en el sector secundario ${ }^{90}$, generando un total de 34.000 millones de dólares anuales de beneficio, lo que supone una cantidad de $4.800 \$$ anuales por víctima ${ }^{91}$. Los casos de trabajos forzosos en este sector se pueden encontrar en todas las regiones ${ }^{92}$. Se estima que hay un total de 460.000 víctimas de trabajo forzado en este sector en las economías desarrolladas y en la UE y 550.000 en los Estados no comunitarios del Este de Europa y de la $\mathrm{CIE}^{93}$. Muchas personas provenientes de países en vías de desarrollo migran a países ricos en los que son explotados en el sector de la construcción. La OIT identifica que este es el caso de los trabajadores migrantes asiáticos en Oriente Medio, de los trabajadores del Este de Europa que migran a otros países de la región con más recursos y de las migraciones intrarregionales e internacionales que en la UE y en Norte América ${ }^{94}$. Otros ámbitos del sector secundario en los que el trabajo forzado está especialmente presente es en la industria de la fabricación de ladrillos y en el sector textil.

Al igual que en sector primario, resulta sorprendente la ausencia de casos que hayan llegado ante el TEDH en los que el Tribunal haya tenido que analizar el alcance del CEDH en relación con trabajos del sector secundario. De nuevo, y sin perjuicio de que algún caso se haya quedado fuera del alcance de esta investigación, el único caso relevante que se ha encontrado ha sido el asunto Zhelyazkov c. Bulgaria95, relativo a una persona obligada a trabajar en la construcción de obras públicas como parte de una condena judicial.

El caso Zhelyazkov c. Bulgaria ${ }^{96}$ explora los límites del trabajo forzado en el sector secundario, reafirma el carácter evolutivo del CEDH y delimita el alcance del apartado 4§3a) del CEDH. Zhelyazkov era un ciudadano húngaro que fue condenado a 15 días de privación de libertad

89 GRIFFITHS, A; y WALL, S.: Applied Economics. Twelfth Edition, Financial Times Press: Uk, 2011. P. 2 (traducción propia del inglés).

90 INTERNATIONAL LABOUR OFFICE (ILO): Profits and Poverty: The Economics of Forced Labour. ILO publications: Geneva, 2014. P.18. La clasificación incluye: construcción, manufactura, trabajo en fábricas y minería (nótese que esta última pertenece al sector primario, no al secundario).

${ }^{91}$ Ibídem. P. 16.

92 Ibídem. P. 19.

93 Ibídem. P. 18.

${ }^{94}$ Ibídem. P. 19.

${ }^{95}$ Zhelyazkov c. Bulgaria, no. 11332/04. [TEDH; Sección IV], 09 de octubre de 2012.

${ }^{96}$ Zhelyazkov c. Bulgaria, no. 11332/04. [TEDH; Sección IV], 09 de octubre de 2012. 
de acuerdo con un decreto para combatir el vandalismo leve ${ }^{97}$ por haber tenido un altercado con un fiscal y haber intentado agredir a un policía. Durante dicho periodo de detención, Zhelyazkov fue obligado a trabajar en una obra pública en el municipio de Tsarevo, Bulgaria, sin recibir remuneración alguna98. El TEDH falló que el hecho de que el trabajo no fuera remunerado no se traduce automáticamente en una vulneración del artículo $4 \mathrm{CEDH}$. En este sentido, el TEDH citó la jurisprudencia sentada en el caso Veintiuna personas detenidas c. Alemania99, en el que se declaró que "el artículo 4 no contiene ninguna disposición relativa a la remuneración de los prisioneros por su trabajo"100. No obstante, el TEDH señaló que "ha habido una evolución posterior en las actitudes respecto a dicho asunto, reflejada en las Reglas de Prisión Europeas de $1987^{101}$ y de $2006^{102}$, que apoyan una remuneración equitativa del trabajo de los prisioneros - con las Reglas de 2006 añadiendo «en todo caso»"103. Esta reflexión del TEDH reafirma el carácter evolutivo del CEDH como un instrumento vivo ${ }^{104}$ y deja la puerta abierta a que en el futuro la obligatoriedad de realizar trabajos en prisión deba ir acompañada necesariamente de una remuneración adecuada. Tan solo un año más tarde, en 2013, el TEDH ha recurrido a las normas sobre la remuneración equitativa de las Reglas de Prisión Europeas de 2006 en su decisión de inadmisión en el asunto Floroiu c. Rumanía ${ }^{105}$. A pesar de que se pueda empezar a vislumbrar una tendencia del TEDH para incorporar los requisitos de las Reglas de Prisión Europeas de 2006 a la interpretación del artículo 4 del $\mathrm{CEDH}^{106}$, aún resulta temprano para deducir que la falta de remuneración equitativa puede acarrear por sí sola una violación del artículo.

97 "The 1963 Decree on Combating Minor Hooliganism". Citado en Zhelyazkov c. Bulgaria, no. 11332/04. [TEDH, Sección IV], 09 de octubre de 2012 párr. 10.

98 Zhelyazkov c. Bulgaria, no. 11332/04. [TEDH, Sección IV], 09 de octubre de 2012. Párr. 8.

99 Veintiuna personas detenidas c. Alemania, nos. 3134/67, 3172/67, 3188-3206/67 [TEDH], 6 de abril de 1968.

100 Zhelyazkov c. Bulgaria, no. 11332/04. [TEDH, Sección IV], 09 de octubre de 2012, párr. 36 (traducción propia del inglés).

${ }_{101}$ COMMITTEE OF MINISTERS, Recommendation No. R (1987) 3 on the European Prison Rules (Adopted by the Committee of Ministers on 12 February 1987 at the 404th meeting of the Ministers' Deputies.

102 COMMITTEE OF MINISTERS, Recommendation No. R (2006) 2 on the European Prison Rules (Adopted by the Committee of Ministers on 11 January 2006 at the 952 nd meeting of the Ministers'Deputies).

103 Zhelyazkov c. Bulgaria, no. 11332/04. [TEDH, Sección IV], 09 de octubre de 2012, párr. 36 (traducción propia del inglés); ver también Stummer c. Austria, no. 37452/02. [TEDH, Gran Sala], 07 de julio de 2011, párr. 130.

104 Tyrer c. Reino Unido, no. 5856/72. [TEDH], 25 de abril de 1978, párr. 31; Pichkur c. Ucrania, no. 10441/06. [TEDH], 07 de noviembre de 2013, párr. 53; Vallianatos y Otros c. Grecia, nos. 29381/09 y 32684/09. [TEDH], 7 de noviembre de 2013, párr. 84.

105 Floroiu c. Rumanía (extracts), no. 15303/10. [TEDH, Sección III], 12 de marzo de 2013.

${ }^{106}$ En este sentido ver también: Stummer c. Austria, no. 37452/02. [TEDH, Gran Sala], 07 de julio de 2011, párr. 132. 
Por otro lado, el TEDH tuvo la oportunidad en el caso Zhelyazkov de estudiar el alcance de la letra a) del apartado 4§3: "no se considera como "trabajo forzado u obligatorio" en el sentido del presente artículo: a) todo trabajo exigido normalmente a una persona privada de libertad en las condiciones previstas por el artículo 5 del presente Convenio, o durante su libertad condicional". Zhelyazkov alegó que el trabajo exigido no se ajustaba a lo dispuesto el apartado 4§3a) ya que la detención no había contemplado las reglas previstas por el artículo 5 del $\mathrm{CEDH}$ al haberse fundado en un decreto y no en una ley parlamentaria ${ }^{107}$. El TEDH concluyó que no había habido violación del apartado 4§3a) con base en los siguientes cuatro motivos: (i) el TEDH ya había fallado en una decisión anterior sobre el mismo caso que no había habido violación del artículo 5 del $\mathrm{CEDH}^{108}$; (ii) "el término 'derecho' en el artículo $5 \S 1$ del Convenio ha de ser entendido en su sentido sustancial, no en su formal"109; (iii) el detenido había sido informado de las razones de su detención en los términos del artículo $5 \S 2^{110}$ y (iv) su detención había sido sujeta a control judicial de acuerdo con el artículo $5 \S 4^{111}$.

A pesar de que el TEDH consideró que Bulgaria no había violado la prohibición de someter a Zhelyazkov a trabajos forzados u obligatorios, resulta pertinente a raíz de este caso, adelantar el estudio de las dimensiones del problema del trabajo forzoso impuesto por los Estados ya que, como se verá en la sección siguiente (3. Sector terciario/Sector servicios), el TEDH ya ha condenado a un Estado parte del CEDH por constreñir a una persona a realizar trabajos forzados u obligatorios ${ }^{112}$. El trabajo forzado impuesto por los Estados puede revestir diversas formas, entre las que se incluyen: el trabajo en prisión, en fuerzas armadas y en cuerpos paramilitares. La OIT calcula que 2,2 millones de personas son explotadas en trabajos impuestos por los Estados, lo que supone un 10\% del total de víctimas del trabajo forzado ${ }^{113}$. Muchos de los Estados que actualmente son del $\mathrm{CEDH}$ han tenido graves episodios de trabajos forzados impuestos desde el gobierno como la construcción del Valle de los Caídos en España, los campos de trabajo en la Unión Soviética, los

107 Zhelyazkov c. Bulgaria, no. 11332/04. [TEDH, Sección IV], 09 de octubre de 2012. Párr. 30.

108 Zhelyazkov c. Bulgaria (dec.), no. 11332/04, [TEDH, Sección V] 12 de mayo de 2009

109 El TEDH, a continuación, destacó que "[E]I Tribunal ha aceptado que la detención puede estar basada en una costumbre suficientemente asentada (ver Drozd and Janousek v. Francia y España, 26 junio 1992, § 107, Series A no. 240) o en jurisprudencia (ver Steel y Otros c. Reino Unido, 23 septiembre 1998, § 55, Reports of Judgments and Decisions 1998-VII). Ha adoptado la misma postura frente al término "derecho" que es usada en los artículos 8 y 10 de la Convención (ver Kruslin c. Francia, 24 abril 1990, § 29, Series A no. 176-A y The Sunday Times c. Reino Unido no. 1, 26 abril 1979, § 47, Series A no. 30)". Zhelyazkov c. Bulgaria, no. 11332/04. [TEDH, Sección IV], 09 de octubre de 2012. Párr. 31 (traducción propia del inglés).

${ }^{110}$ Ibídem Párr. 32.

${ }^{111}$ Ibídem Párr. 33.

112 Ver: Chitos c. Grecia, no. 51637/12. [TEDH, Sección I], 04 de junio de 2015.

113 INTERNATIONAL LABOUR OFFICE (ILO): Profits and Poverty: The Economics of Forced Labour. ILO publications: Geneva, 2014. P.7. 
campos de concentración en la Alemania de Hitler, la Francia de Vichy y la Italia de Mussolini o la utilización de la población nativa congoleña como esclavos por el rey Leopoldo II de Bélgica.

\section{3.- Sector terciario/sector servicios}

Romero Amado pone de relieve la dificultad de delimitar el concepto de sector terciario y advierte que la "falta de precisión en la conceptualización de los servicios acarrea problemas en el establecimiento de criterios claros para clasificarlos"114. González, del Río y Domínguez señalan que a pesar de la heterogeneidad de las actividades económicas que engloba, el sector terciario se puede definir en términos generales como "las actividades que no producen bienes"115. Teniendo en cuenta la enorme variedad de actividades que se encuentran recogidas bajo esta clasificación, este artículo sólo analizará las actividades sobre las que el TEDH se haya tenido que pronunciar. Sin ánimo de hacer una clasificación exhaustiva, esta sección analizará: (a) el trabajo doméstico, (b) el trabajo del sexo, (c) el sector sanitario, (d) el cuerpo de bomberos, (e) el sector de la justicia, (f) la restauración, ( $g$ ) el servicio militar y (h) el sector de la investigación.

\subsection{1.- Trabajo doméstico}

Como bien indicó el TEDH, "a pesar de que la esclavitud haya sido abolida oficialmente hace más de 150 años, la 'servidumbre doméstica' persiste en Europa y concierne a miles de personas, la mayoría de ellas mujeres"116. De acuerdo con los datos de la OIT, el trabajo doméstico forzado afecta a un total de 3,44 millones de personas en el mundo, de las cuales 30.000 se encuentran en las economías desarrolladas y en la UE y un número equivalente en los Estados no comunitarios del Este de Europa y de la $\mathrm{CIE}^{117}$. Anualmente, el trabajo doméstico forzado genera unos beneficios de 7.800 millones de dólares. La OIT estima que las empleadas del hogar se ven privadas (o, en palabras de la OIT, "literalmente robadas") de un $60 \%$ de sus salarios anuales. En la UE y en las economías desarrolladas el trabajo forzado doméstico genera unos beneficios de 200 millones de dólares, mientras que en Estados no comunitarios del Este de Europa y de la CIE la cifra es de 100 millones de

\footnotetext{
${ }^{114}$ ROMERO AMADO, J. El sector servicios en la economía: el significado de los servicios a empresas intensivos en conocimiento. Artículo disponible online: http://herzog.economia.unam.mx/lecturas/inae3/romeroaj.pdf

115 GONZÁLEZ MORENO, M; DEL RÍO GÓMEZ, C; y DOMÍNGUEZ MARTÍNEZ, JM.: "Los servicios: concepto, clasificación y problemas de medición". Ekonomiaz no. 13-14, 1989, Pp. 10-19.

116 Siliadin C. Francia, no. 73316/01. [TEDH, Sección II], 26 de julio de 2005, párr. 111 (traducción propia del inglés).

117 INTERNATIONAL LABOUR OFFICE (ILO): Profits and Poverty: The Economics of Forced Labour. ILO publications: Geneva, 2014. P.25.
} 
dólares ${ }^{118}$. En términos de beneficio anual por víctima, se encuentran por orden decreciente: las economías desarrolladas y la UE (7.500\$), la región de Asia-Pacifico (3.300\$), los Estados no comunitarios del Este de Europa y de la CIE (1.700\$), el Oriente Medio (1.400\$), Latinoamérica y el Caribe $(800 \$)$ y África $(600 \$)^{119}$.

En el reciente informe de la Comisión Europea sobre avance de la lucha contra la trata de 19 de mayo de 2016, se destacó que la explotación doméstica es particularmente difícil de detectar ya que las víctimas se encuentran aisladas y prácticamente sin posibilidad de denunciar su situación o escapar de ella ${ }^{120}$. En el documento de trabajo sobre dicho informe, se detalla que la mayoría de las víctimas de la trata con fines de explotación doméstica son mujeres y niñas seducidas por ofertas de empleo falsas o por publicidad online sobre visados ${ }^{121}$.

La servidumbre doméstica y el trabajo forzado doméstico han tenido una gran importancia en la interpretación del artículo 4 del CEDH. El 50\% de los casos en los que el TEDH ha fallado que un Estado parte del CEDH ha violado el artículo 4 del CEDH ha tratado sobre este problema ${ }^{122}$. Además, la fundamentación jurídica de dichas sentencias ha tenido una gran repercusión no solo en la interpretación del artículo 4 del CEDH, sino también en sentencias y decisiones sobre otros artículos. Por estos motivos, los casos que se analizan a continuación se estudiarán en especial detalle.

El caso Siliadin $v$. France ${ }^{123}$ constituye la piedra angular de la interpretación del alcance del artículo 4 del CEDH. En él, el TEDH falló por primera vez que un Estado parte había violado la prohibición del artículo 4 del CEDH. Además, tal y como White y Ovey señalan, el TEDH, al conectar el fenómeno moderno de la trata de seres humanos y la servidumbre doméstica con el concepto histórico del trabajo forzado, servidumbre y esclavitud, "dio una nueva vida al artículo 4 "124. El caso Siliadin sentó los principios de interpretación del artículo 4 del CEDH sobre los que han basado explícitamente la práctica totalidad de las sentencias condenatorias posteriores ${ }^{125}$.

\footnotetext{
${ }^{118}$ Ibídem.

${ }^{119}$ Ibídem.

120 COMMISSION TO THE EUROPEAN PARLIAMENT AND THE COUNCIL. Report on the progress made in the fight against trafficking in human beings (2016). Brussels, 19.5.2016 COM(2016) 267 final, P. 6.

${ }^{121}$ COMMISSION TO THE EUROPEAN PARLIAMENT AND THE COUNCIL. Commission Staff Working Document Accompanying the Report on the progress made in the fight against trafficking in human beings (2016). Brussels, 19.5.2016 SWD (2016) 159 final.

122 Ver: Siliadin c. Francia, no. 73316/01. [TEDH, Sección II], 26 de julio de 2005; C.N. y V. c. Francia, no. 67724/09. [TEDH, Sección V], 11 de octubre de 2012; C.N. C. Reino Unido, no. 4239/08. [TEDH, Sección IV], 13 de noviembre de 2012.

${ }^{123}$ Siliadin c. Francia, no. 73316/01. [TEDH, Sección II], 26 de julio de 2005.

${ }^{124}$ WHITE, R. \& OVEY, C. The European Convention on Human Rights. OUP: Oxford 2010 50 ed, P. 198.

${ }^{125}$ El único caso en el que el TEDH ha encontrado una violación del artículo 4 del CEDH sin apoyarse explícitamente en el caso Siliadin ha sido en el caso Chitos c. Grecia (2015, no. 51637/12). Ver menciones expresas al caso Siliadin en: C.N. y V. C. Francia, no.
} 
Siliadin Ilegó a Francia procedente de Togo en 1995 con la edad de 15 años bajo el acuerdo con el Sr. y la Sra. D. de que tendría que trabajar como empleada del hogar hasta haber cubierto el coste del billete de avión y, a cambio, ellos tramitarían sus papeles de inmigración y la encontrarían una plaza en el colegio ${ }^{126}$. Sin embargo, cuando llegó a Francia el matrimonio le requisó su pasaporte ${ }^{127}$ y se vio obligada a trabajar 15 horas al día (de 7:30 a 22:30) durmiendo sobre la alfombra del cuarto del bebé ${ }^{128}$, sin recibir remuneración alguna ${ }^{129}$ y sin que su situación se regularizara ${ }^{130}$. Además, trabajada los 7 días de la semana, sin disfrutar de ningún día libre y sólo podía salir ocasionalmente para ir a misa $^{131}$. En 1998 consiguió recuperar su pasaporte $y$, con ayuda de un vecino, contactó con el Comité contre l'esclavage moderne, quien denunció los hechos ante la fiscalía ${ }^{132}$. El 15 de mayo de 2003 el Tribunal de Apelación de Versalles condenó al Sr. y la Sra. D. a indemnizar a Siliadin en concepto de daños y perjuicios ${ }^{133}$. Dos años más tarde, el 1 de febrero de 2005 la Sala del TEDH declaró admisible la demanda ${ }^{134}$ y el 26 de julio de 2005 el TEDH condenó a Francia por no haber cumplido con sus obligaciones positivas emanantes del artículo $4 \mathrm{CEDH}$. El desarrollo del argumento con el que el TEDH falló que Francia había vulnerado el artículo 4 del CEDH sigue los siguientes pasos: (i) determinación de los elementos del trabajo forzado ${ }^{135}$, (ii) evaluación de los hechos como servidumbre y esclavitud ${ }^{136}$ y (iii) análisis de las obligaciones positivas de Francia ${ }^{137}$.

Primero, el TEDH analizó si los hechos podían considerarse como trabajo forzado. Para ello, recurrió a los dos elementos enunciados en el caso Van der Mussele ${ }^{138}$, que a su vez se basan en la definición de "trabajo forzoso u obligatorio" del artículo $2 \S 1$ del Convenio de la OIT no. 29 relativo al trabajo forzoso u obligatorio ${ }^{139}$. Estos dos elementos son:

67724/09. [TEDH, Sección V], 11 de octubre de 2012. Párr. 107; C.N. C. Reino Unido, no. 4239/08. [TEDH, Sección IV], 13 de noviembre de 2012, Párr. 76; Rantsev c. Chipre y Rusia, no. 25965/04. [TEDH, Sección I], 7 de enero de 2010. Párr. 282; L.E. c. Grecia, no. 71545/12. [TEDH, Sección I], 21 de enero de 2016. Párr. 35, 64.

${ }^{126}$ Ibídem párr. 10-11, 109.

${ }^{127}$ Ibídem párr. 11.

128 Ibídem párr. 14.

${ }^{129}$ Ibídem párr. 15.

${ }^{130}$ Ibídem párr. 17.

${ }^{131}$ Ibídem párr. 25.

132 Ibídem párr. 18.

133 Ibídem párr. 140.

134 Siliadin C. Francia (decisión), no. 73316/01. [TEDH], 1 de febrero de 2005.

135 Siliadin c. Francia, no. 73316/01. [TEDH, Sección II], 26 de julio de 2005, párr. 117120.

${ }^{136}$ Ibídem párr. 121-129.

137 Ibídem párr. 130-149.

138 Van der Mussele c. Bélgica, no. 8919/80. [TEDH, Plenario], 23 de noviembre de 1983; ver misma definición en C.N. y V. C. Francia, no. 67724/09. [TEDH, Sección V], 11 de octubre de 2012. Párr. 71.

${ }^{139} 2 \S 1$ : "A los efectos del presente Convenio, la expresión trabajo forzoso u obligatorio designa todo trabajo o servicio exigido a un individuo bajo la amenaza de una pena 
(a) que el trabajo se haya realizado en contra de la voluntad de la persona afectada, es decir, que la persona no se haya ofrecido voluntariamente a ello y (b) que haya sido ejecutado bajo la amenaza de una sanción. En cuanto al primer requisito, el TEDH afirmó que el trabajo se había realizado en contra de la voluntad de la víctima dado que Siliadin no tuvo otra alternativa ${ }^{140}$. En cuanto al segundo requisito, el TEDH consideró que a pesar de que la víctima no había sido amenazada con ninguna sanción concreta en su sentido ordinario, se encontraba en una situación similar debido a la severidad del temor percibido a ser detenida por la policía de extranjería en Francia ${ }^{141}$. Considero que esta interpretación no restrictiva del requisito de "la amenaza de una sanción" constituye un gran avance para la protección de los inmigrantes en situación irregular víctimas de trabajos forzados ya que, por el mero hecho de no cumplir con los requisitos administrativos de extranjería, se enfrentan a sanciones económicas ${ }^{142}$, detención en centros de internamiento de extranjeros (CIE) ${ }^{143}$ e, incluso, la expulsión del país ${ }^{144}$, lo que les coloca en una posición de especial vulnerabilidad frente al agente explotador.

Segundo, una vez determinado que los hechos podían considerarse como trabajo forzado, el TEDH dio un paso más y valoró si también podrían considerarse como esclavitud o servidumbre. Basándose en el artículo 1 de la Convención sobre la Esclavitud de $1926^{145}$, el TEDH definió el concepto de esclavitud como el ejercicio de un genuino derecho de propiedad legal sobre la persona que la reduce al estatus de un objeto ${ }^{146}$, concluyendo que, si bien la víctima había sido privada de autonomía, no se había ejercido sobre ella un derecho de propiedad propiamente dicho. Una vez descartada la esclavitud, el TEDH pasó a analizar la servidumbre. EI TEDH recurrió a la definición de servidumbre ya enunciada en el caso Van Droogenbroeck consistente en "formas particularmente serias de

cualquiera y para el cual dicho individuo no se ofrece voluntariamente." (1930) Convenio de la OIT no. 29 relativo al trabajo forzoso u obligatorio (Entrada en vigor: 01 mayo 1932).

140 Siliadin c. Francia, no. 73316/01. [TEDH, Sección II], 26 de julio de 2005, párr. 119.

${ }^{141}$ Ibídem párr. 118.

142 Artículo 55 Ley Orgánica 4/2000, de 11 de enero, sobre derechos y libertades de los extranjeros en España y su integración social.

143 Ver: SERVICIO JESUITA A MIGRANTES-ESPAÑA (SJM). CIE y expulsiones exprés informe anual 2014. Madrid, 2014. Informe disponible en: https://cerremosloscies.files.wordpress.com/2011/12/informecie2014.pdf; MARTÍNEZ ESCAMILLA, M. (Dir.): Mujeres en el cie género, inmigración e internamiento. Madrid, 2013. Informe disponible online en: http://perso.unifr.ch/derechopenal/assets/files/obrasjuridicas/oj 20130708 02.pdf

${ }_{144}$ Artículo 57 de la Ley Orgánica 4/2000, de 11 de enero, sobre derechos y libertades de los extranjeros en España y su integración social.

${ }^{145}$ Artículo 1.1. "La esclavitud es el estado o condición de un individuo sobre el cual se ejercitan los atributos del derecho de propiedad o algunos de ellos." (1926) Convención sobre la Esclavitud (entrada en vigor: 9 de marzo de 1927).

146 Siliadin c. Francia, no. 73316/01. [TEDH, Sección II], 26 de julio de 2005, párr. 122 (traducción propia del inglés). 
denegación de la libertad"147 y al informe sobre dicho caso que presentó de la Comisión Europea de Derechos Humanos en el que se afirmaba que, "en todo caso, hay que considerar que además de la obligación de proveer a la otra persona ciertos servicios, la noción de servidumbre engloba la obligación para el siervo de vivir en la propiedad del otro y la imposibilidad de cambiar su condición ${ }^{\prime 148}$. Con base en esta definición, el TEDH afirmó que Siliadin había sido sujeta a un régimen de servidumbre. Para llegar a esta conclusión, el Tribunal de Estrasburgo, partió del hecho de que la Convención "es un instrumento vivo ${ }^{149}$ que tiene que ser interpretado bajo la luz de las condiciones presentes y que los crecientes altos estándares requeridos en el área de la protección de los derechos humanos y de las libertades fundamentales correspondientemente e inevitablemente requieren de una mayor firmeza en la determinación de las violaciones de los valores fundamentales de las sociedades democráticas"150. A pesar de las críticas que ha recibido esta revolucionaria técnica de interpretación ${ }^{151}$, que se separa del carácter estático del artículo 31 de la Convención de Viena sobre el Derecho de los Tratados (CVDT) ${ }^{152}$, estimo que el hecho de que el TEDH considere el CEDH un instrumento vivo supone uno de los avances más importantes en materia de derechos humanos al otorgar un carácter dinámico único al CEDH que asegura que la protección de los derechos de los ciudadanos no se verá nunca amenazada por los avances (o retrocesos) de la sociedad.

Tercero, partiendo de la base de que Siliadin fue sometida a servidumbre, el TEDH valoró si Francia había cumplido con sus obligaciones positivas. La legislación penal francesa no contemplaba como tal ni la servidumbre ni la esclavitud como delitos ${ }^{153}$, sino que, en su lugar, tipificaba los delitos de explotación laboral y sujeción a condiciones

147 Van Droogenbroeck c. Bélgica, no. 7906/77. [TEDH, Plenario], 24 de junio de 1982. Párr. 58 (traducción propia del inglés).

${ }^{148}$ Van Droogenbroeck C. Bélgica (Rapport de la Commission) no. 7906/77. 9 de julio de 1980. Párr. 79 (traducción propia del francés).

149 Énfasis añadido.

150 Siliadin C. Francia, no. 73316/01. [TEDH, Sección II], 26 de julio de 2005, párr. 121 (traducción propia del inglés).

${ }^{151}$ LORD SUMPTION, magistrado del Tribunal Supremo del Reino Unido, sostiene que la técnica del instrumento vivo supone una amenaza a la democracia al poner en manos de los jueces del TEDH el poder legislativo (judge-made law), extendiendo las obligaciones de los países más allá de lo que se comprometieron en su día al ratificar el CEDH. Ver: BOWCOTT, O.: "Senior judge: European court of human rights undermining democratic process". The Guardian, 28 de noviembre de 2013. Online: http://www.theguardian.com/law/2013/nov/28/european-court-of-human-rights

152 El artículo $31 \S 1$ de la Convención de Viena sobre el Derecho de los Tratados determina que para interpretar los términos de un tratado ha de tenerse en cuenta el contexto de estos, y no el contexto de las circunstancias en las que se apliquen. (1969) Convención de Viena sobre el Derecho de los Tratados (Entrada en vigor: 27 de junio de 1980); Ver cómo el TEDH pretende reconciliar la técnica del instrumento vivo con la Convención de Viena sobre el Derecho de los Tratados en Rantsev c. Chipre y Rusia, no. 25965/04. [TEDH, Sección I], 7 de enero de 2010, párr. 273-277.

153 Siliadin C. Francia, no. 73316/01. [TEDH, Sección II], 26 de julio de 2005, párr. 141. 
de trabajo incompatibles con la dignidad ${ }^{154}$. El TEDH sostuvo que la protección del Estado había de materializarse en una legislación disuasoria, en especial cuando la víctima era un menor o persona vulnerable ${ }^{155}$. En este caso, los responsables de haber sometido a la víctima a un régimen de servidumbre no fueron condenados penalmente ${ }^{156} \mathrm{y}$, por tanto, el TEDH consideró que la ley penal vigente no era conforme con el artículo $4 \mathrm{CEDH}^{157}$. Finalmente, el TEDH reconoció que la legislación francesa en esta materia había sido enmendada, aunque advirtió a Francia que los crecientes estándares de protección de los derechos humanos iban a requerir de una mayor firmeza en el futuro ${ }^{158}$. Sin embargo, Francia, que acababa de ser el primer Estado condenado por haber vulnerado el artículo 4 del $\mathrm{CEDH}$, no prestó debida atención al aviso del TEDH y, en 2012, se convirtió en el primer Estado parte del TEDH en sumar una segunda violación de la prohibición de la esclavitud, la servidumbre y el trabajo forzoso u obligatorio a su historial $^{159}$.

El caso C.N. y V. C. Francia $(2012)^{160}$ trata de dos huérfanas burundesas de 10 y 16 años, que huyeron de su país tras la guerra civil, en la que murieron sus padres. Al llegar a Francia, se vieron forzadas a trabajar en la casa de sus tíos, sin recibir remuneración alguna, sin poder disfrutar de días libres y teniendo que ocuparse de los hijos del matrimonio, siendo uno de ellos minusválido. Además, tenían que dormir en el sótano en condiciones insalubres sin acceso a un cuarto de baño y sufrían un continuo acoso físico y verbal. EI TEDH diferenció las condiciones de la hermana menor y la mayor, sosteniendo que, dado que la hermana menor podía ir al colegio, hacer sus deberes y tenía menos carga en las labores del hogar su situación se encontraba fuera del alcance del artículo 4 del CEDH ${ }^{161}$. Para el examen del caso de la hermana mayor, el TEDH vuelve a seguir la misma estructura y argumentación que en el caso Siliadin.

Primero, el TEDH analizó los elementos del trabajo forzado ${ }^{162}$, afirmando que el trabajo había sido realizado en contra de la voluntad de

\footnotetext{
${ }^{154}$ Ver cómo el concepto de dignidad define las relaciones laborales en Francia en el caso Dwarf-tossing (lanzamiento de enanos). Manuel Wackenheim c. Francia. Comunicación No 854/1999, U.N. Doc. CCPR/C/75/D/854/1999 (2002).

155 Siliadin c. Francia, no. 73316/01. [TEDH, Sección II], 26 de julio de 2005, párr. 143.

${ }^{156}$ Ibídem párr. 145.

157 Ibídem párr. 148.

${ }^{158}$ Ibídem.

159 Hasta principios de 2016, Francia era el único Estado con dos sentencias condenatorias en su historial por vulnerar el artículo 4 del CEDH. En enero de 2016, Grecia sumó su segunda violación del artículo 4 CEDH con el caso L.E. c. Grecia, no. 71545/12. [TEDH], 21 de enero de 2016.

${ }^{160}$ C.N. y V. c. Francia, no. 67724/09. [TEDH, Sección V], 11 de octubre de 2012.

${ }^{161}$ Ibídem párr. Párr. 62.

162 Ver requisitos en Van der Mussele c. Bélgica, no. 8919/80. [TEDH, Plenario], 23 de noviembre de 1983; Siliadin c. Francia, no. 73316/01. [TEDH, Sección II], 26 de julio de 2005, párr. 117-120.
} 
la víctima ${ }^{163}$ y que se había realizado bajo la amenaza de que su situación irregular en Francia motivase su expulsión del país ${ }^{164}$. Por tanto, el Tribunal concluyó que la víctima había sido constreñida a trabajos forzados ${ }^{165}$.

Segundo, el TEDH valoró si las circunstancias alcanzaban la gravedad de la servidumbre. Para ello, partió del requisito objetivo expuesto en el caso Van Droogenbroeck ${ }^{166}$ y reafirmado en el caso Siliadin ${ }^{167}$ : que haya una obligación bajo coacción de realizar servicios a otra persona que derive en una forma particularmente seria de privación de la libertad ${ }^{168}$. A este requisito objetivo, el Tribunal añade un requisito subjetivo, consistente en "la creencia de la víctima de que su condición es permanente y que es poco probable que su situación cambie"169. Con base en los anteriores dos requisitos, el TEDH concluye que la víctima había sido sujeta a servidumbre ${ }^{170}$. Bajo mi punto de vista, el hecho de que se requiera un elemento subjetivo adicional no menoscaba el alcance de la prohibición de la servidumbre, sino que completa su significado y fortalece su definición legal, lo que radica en una mayor seguridad jurídica tanto para las víctimas de la servidumbre como para los Estados Parte que han de acatar los términos del CEDH.

Tercero, el TEDH estudió el cumplimiento de Francia de sus obligaciones positivas, concluyendo que "el Tribunal no [veía] razones en el presente caso para desviarse de su sentencia en el caso Siliadin" puesto que "la situación legislativa nacional era la misma"171. Las enmiendas hechas a la legislación en 2003 a las que el TEDH se refirió en el caso Siliadin ${ }^{172}$ no sirvieron para cambiar las conclusiones del Tribunal de Estrasburgo ${ }^{173}$.

La semejanza de los hechos del caso Siliadin (2005) con el caso C.N. y V (2012), así como la simetría del razonamiento del TEDH en una u otra sentencia, demuestran la pasividad con la que Francia se enfrentó al problema de la servidumbre y el trabajo forzado en el ámbito del empleo doméstico. La falta de diligencia con la que se ha abordado la lucha contra la servidumbre doméstica no ha sido un problema únicamente francés, sino que afecta a otros Estados parte del CEDH. Junto con Francia, el Reino Unido también ha sido condenado (C.N. C. Reino Unido) por no

${ }^{163}$ C.N. y V. C. Francia, no. 67724/09. [TEDH, Sección V], 11 de octubre de 2012. Párr. 76.

${ }^{164}$ Ibídem párr. 78.

${ }^{165}$ Ibídem párr. 79.

166 Van Droogenbroeck c. Bélgica, no. 7906/77. [TEDH, Plenario], 24 de junio de 1982. Párr. 58.

167 Siliadin c. Francia, no. 73316/01. [TEDH, Sección II], 26 de julio de 2005, párr. 98.

168 C.N. y V. C. Francia, no. 67724/09. [TEDH, Sección V], 11 de octubre de 2012. Párr. 89.

${ }^{169}$ Ibídem párr. 91 (traducción propia del inglés).

${ }^{170}$ Ibídem párr. 94.

${ }^{171}$ Ibídem párr. 107 (traducción propia del inglés).

172 Siliadin C. Francia, no. 73316/01. [TEDH, Sección II], 26 de julio de 2005, párr. 148

173 C.N. y V. C. Francia, no. 67724/09. [TEDH, Sección V], 11 de octubre de 2012. Párr. 107. 
tener una legislación capaz de abordar la servidumbre doméstica de forma efectiva y penar a sus responsables.

En el caso C.N. C. Reino Unido -relativo a una mujer senegalesa, víctima de servidumbre doméstica, a la que su pasaporte fue retirado, y cuya solicitud de asilo en el Reino Unido fue denegada- el TEDH afirmó que "a la vista de la conclusión del Tribunal en Siliadin, no puede sino concluir que las disposiciones legislativas en vigor en el Reino Unido durante el tiempo relevante eran inadecuadas para aportar una protección práctica y efectiva contra un tratamiento que caía dentro del alcance del artículo 4 del Convenio"174.

Tras la sentencia del caso C.N. de noviembre de 2012, el Reino Unido reaccionó y, en marzo de 2013, revisó su declaración unilateral en el caso Kawogo c. Reino Unido ${ }^{175}$, que estaba pendiente de resolución. En ella, el Reino Unido reconoció que su legislación había sido inadecuada para aportar una protección efectiva a una mujer tanzana obligada a trabajar en casa de su antiguo empleador cuando su visado expiró. Además, el Reino Unido aceptó que había contravenido sus obligaciones positivas procedimentales bajo el artículo 4 del CEDH al no haber estudiado el posible enjuiciamiento criminal de las personas responsables de la servidumbre doméstica. Teniendo en cuenta estas declaraciones, así como la compensación económica que el gobierno británico ofreció a la víctima, el TEDH decidió en septiembre de 2013 archivar el caso de acuerdo con el artículo 37§1.c) del $\mathrm{CEDH}^{176}$.

\subsection{2. - Trabajo del sexo}

De acuerdo con la OIT, el $22 \%$ del trabajo forzado mundial se produce en la industria sexual ${ }^{177}$. Este porcentaje se traduce en 4 millones y medio de personas sometidas a explotación sexual ${ }^{178}$. La OIT estima que las ganancias económicas anuales procedentes de la explotación sexual forzada son de 33.900 millones de dólares, de las cuales 27.800 millones corresponden a la trata de seres humanos. De esta última cifra, cerca de la mitad, 13.300 millones de dólares, se obtienen de países industrializados ${ }^{179}$. Tanto en la UE y en las economías desarrolladas como en los Estados no comunitarios del Este de Europa y de la CIE, se cree que hay 300.000 personas víctimas de explotación sexual en cada una de las dos regiones. Mientras que en la región que incluye a los países del Este de Europa se estima que el beneficio anual de

\footnotetext{
${ }^{174}$ C.N. C. Reino Unido, no. 4239/08. [TEDH, Sección IV], 13 de noviembre de 2012, párr. 76 (traducción propia del inglés).

${ }^{175}$ Kawogo c. Reino Unido (Caso Comunicado), no. 56921/09. [TEDH, Sección IV], 23 de junio de 2010.

176 Kawogo c. Reino Unido (Decisión), no. 56921/09. [TEDH, Sección IV], 3 de septiembre de 2013.

177 INTERNATIONAL LABOUR OFFICE (ILO): Profits and Poverty: The Economics of Forced Labour. ILO publications: Geneva, 2014. P.7.

${ }^{178}$ Ibídem.

${ }^{179}$ Ibídem. Pág 11.
} 
estas prácticas es de 14.300 millones de dólares (42.000\$ anuales ó 5.040 \$ mensuales de ganancias por víctima), en el grupo en el que la UE está clasificada, las ganancias alcanzan los 26.200 millones de dólares (80.000\$ anuales ó $9.540 \$$ mensuales de ganancias por víctima ${ }^{180}$.

El informe de la Comisión Europea (no del CdE) sobre el avance de la lucha contra la trata de mayo de 2016 arroja algunos datos significativos sobre las dimensiones de la trata en la UE. A continuación, se transcriben y traducen algunas de las principales cifras:

«En total hubo 15.846 'víctimas registradas' (tanto identificadas como presumidas) de trata en la UE

La trata con fines de explotación sexual es aún la forma más extendida (67\% de las víctimas registradas), seguida por la explotación laboral (21\% de las víctimas registradas). El otro $12 \%$ fueron registrados como víctimas de trata con otros fines de explotación.

$(76 \%)$

Más de tres cuartos de las víctimas registradas eran mujeres

Al menos un $15 \%$ de las víctimas registradas eran niños

El $65 \%$ de las víctimas registradas eran ciudadanos de la UE

Los cinco países de la UE con más ciudadanos registrados como víctimas en 2013-2014 fueron Rumanía, Bulgaria, los Países Bajos, Hungría y Polonia. Estos fueron a su vez algunos de los Estados para los años 2010-2012

Los cinco países de no comunitarios con más ciudadanos registrados como víctimas en 2013-2014 fueron Nigeria, China, Albania, Vietnam y Marruecos. ${ }^{181}$

El asunto Rantsev c. Chipre y Rusia ${ }^{182}$ es, junto con el caso Siliadin, uno de los casos del TEDH que más trascendencia ha tenido en la interpretación del alcance de las obligaciones positivas de los Estados bajo el artículo 4 del CEDH. Además, en él, el TEDH extiende expresamente el alcance de la prohibición del trabajo forzado, la servidumbre y la esclavitud a la trata de seres humanos, dando un paso que, hasta la fecha, el TEDH no se había atrevido a dar.

Rantsev era el padre de Rantseva, una joven rusa que se fue a Chipre el 5 de marzo de 2001 con un visado de artista ${ }^{183}$. El 12 de marzo, Rantseva consiguió un permiso de trabajo en Chipre y comenzó a trabajar en un cabaret el día 16 de ese mismo mes $^{184}$. Tres días más tarde, abandona el cabaret y el dueño del local avisa a la policía con la intención de que la arrestasen y la expulsasen del país. El 28 de marzo, una mujer que trabajaba en el cabaret localiza a Rantseva en otro local y avisa a su

\footnotetext{
180 Ibídem. P. 27.

181 COMMISSION TO THE EUROPEAN PARLIAMENT AND THE COUNCIL. Report on the progress made in the fight against trafficking in human beings (2016). Brussels, 19.5.2016 COM(2016) 267 final, P. 4.

182 Rantsev c. Chipre y Rusia, no. 25965/04. [TEDH, Sección I], 7 de enero de 2010.

183 Rantsev c. Chipre y Rusia, no. 25965/04. [TEDH, Sección I], 7 de enero de 2010. Párr. 15.

184 Ibídem Párr. 16.
} 
jefe, quien se traslada al lugar para apresarla y llevarla a comisaría ${ }^{185}$. Una vez en comisaría la policía recibe instrucciones de la brigada de extranjería para liberarla cuando llegase el empresario del cabaret a por ella ${ }^{186}$. Cuando se presenta, la policía le entrega el pasaporte y la documentación de la artista y le permite llevársela con él ${ }^{187}$. A las 6:30 a.m. el cuerpo de Rantseva es encontrado inerte en la calle bajo su apartamento $^{188}$. El padre de la víctima, alegó ante el TEDH que las autoridades chipriotas no habían hecho todo lo posible para proteger a su hija de la trata mientras estaba en vida, no habían investigado adecuadamente las circunstancias de su muerte y no habían castigado suficientemente a los responsables. Además, denunció a Rusia por no haber evitado que su hija cayera en manos de la trata y no haber cumplido con sus obligaciones de investigación.

La primera cuestión para el TEDH fue determinar si la trata entraba dentro del ámbito de aplicación del artículo 4 del CEDH ya que no hay mención alguna a ella en el articulado de la Convención. De hecho, Rusia alegó que, dado que los hechos no encajaban en la definición de trabajo forzado, servidumbre o esclavitud, la demanda debía ser inadmitida ratione materiae ${ }^{189}$. El TEDH, tras una amplia argumentación sobre los criterios de interpretación del CEDH (contexto, objeto y propósito del $\mathrm{CEDH}^{190}$, normas de derecho internacional aplicables entre las partes ${ }^{191}$, principio de protección efectiva ${ }^{192}$ y doctrina del instrumento vivo ${ }^{193}$, inter alia), llegó a la conclusión que "la trata en sí misma, según el artículo 3 a) del Protocolo de Palermo y el artículo 4 a) del Convenio contra la trata de seres humanos, entra dentro del ámbito del artículo 4 del Convenio"194, considerando "innecesario identificar si el trato por el que reclama el demandante constituye 'esclavitud', 'servidumbre' o 'trabajo forzoso y obligatorio"195. Con el fin de definir el concepto de trata a los efectos de la prohibición del artículo 4 del CEDH, el TEDH sostuvo que:

"El Tribunal considera que la trata de seres humanos, por su propia naturaleza y afán de explotación, se basa en el ejercicio de potestades vinculadas al derecho de propiedad. Trata a los seres humanos como mercancía que puede ser comprada y vendida y sometida a trabajo forzado, con frecuencia a cambio de una remuneración minúscula o

\footnotetext{
185 Ibídem Párr. 18.

${ }^{186}$ Ibídem Párr. 20.

187 Ibídem Párr. 21.

188 Ibídem Párr. 25.

189 Ibídem Párr. 209.

190 Artículo 31.1 de la Convención de Viena sobre el Derecho de los Tratados de 1969.

${ }^{191}$ Artículo 31.3.c) de la Convención de Viena sobre el Derecho de los Tratados de 1969.

192 Soering C. Reino Unido, no. 14038/88. [TEDH, Plenario], 7 de julio de 1989. Párr. 87, 90.

193 Selmouni c. Francia, no. 25803/94. [TEDH, Gran Sala], 28 de julio de 1999. Párr. 101; Tyrer c. Reino Unido, no. 5856/72. [TEDH, Sala], 25 de abril de 1978. Párr. 31; Siliadin c. Francia, no. 73316/01. [TEDH, Sección II], 26 de julio de 2005, párr. 121.

${ }_{194}$ Rantsev c. Chipre y Rusia, no. 25965/04. [TEDH, Sección I], 7 de enero de 2010. Párr. 282 (traducción al español por el COE/ECHR).

${ }^{195}$ Ibídem.
} 
inexiste, habitualmente en la industria del sexo, pero también en otras. Implica la estrecha vigilancia de las actividades de las víctimas, cuyos movimientos se ven con frecuencia circunscritos. Conlleva el uso de violencia y amenazas contra las víctimas, que viven y trabajan en pobres condiciones." 196

Mediante la ampliación del alcance de la prohibición del artículo 4 del CEDH a la trata, el TEDH actualizó el concepto de esclavitud y tráfico de esclavos a la realidad del siglo XXI, haciendo muestra del poder de la doctrina del instrumento vivo para avanzar en la construcción de una sociedad mejor. El organismo Interights, que participó en el caso como amicus curiae, señaló acertadamente que la trata de seres humanos es "la forma moderna del antiguo comercio mundial de esclavos"197.

En un comentario anterior a la sentencia Rantsev c. Chipre y Rusia, WHITE y OVEY ya especularon que el TEDH iba a ampliar el principio sentado en Siliadin para interpretar el CEDH a la luz del Convenio del CdE Contra la trata de Seres Humanos de 2005 haciendo una mención específica a la trata de seres humanos ${ }^{198}$. Este pronóstico se materializó en 2010, el mismo año de la publicación de su manual sobre el CEDH. En Rantsev el TEDH definió la trata "según el artículo 3 a) del Protocolo de Palermo y el artículo 4 a) del Convenio contra la trata de seres humanos"199. Al recurrir al Protocolo de Palermo de $2000^{200}$ y al Convenio del CdE Contra la Trata de Seres Humanos de $2005^{201}$ para definir el concepto de trata202, el TEDH consiguió canalizar el alcance de sus disposiciones, dotando de forma indirecta al contenido de estos dos instrumentos de un control jurisdiccional del que carecían. Mediante esta técnica de interpretación holística, el TEDH está consiguiendo cohesionar y armonizar los diferentes instrumentos de derechos humanos, dando forma al sistema regional de protección de derechos humanos más avanzado del mundo. No obstante, considero que el TEDH ha de ser cauto al recurrir de forma tan directa a otros instrumentos internacionales (ya sean vinculantes o no) para ampliar las obligaciones de los Estados parte del CEDH puesto que, de aplicar esta técnica de forma extensiva, se podría menoscabar la soberanía de los Estados y se pondría en peligro propia la supervivencia del CEDH. Esta observación cobra especial

\footnotetext{
${ }^{196}$ Ibídem Párr. 281 (traducción al español por el COE/ECHR).

197 Ibídem Párr. 281161 (traducción al español por el COE/ECHR).

198 WHITE, R. \& OVEY, C. The European Convention on Human Rights. OUP: Oxford 2010 50 ed, P. 208.

199 Rantsev C. Chipre y Rusia, no. 25965/04. [TEDH, Sección I], 7 de enero de 2010. Párr. 282 (traducción al español por el COE/ECHR).

200 (2000) Protocolo de las Naciones Unidas para Prevenir, Reprimir y Sancionar la Trata de Personas, especialmente Mujeres y Niños de 2000 (entrada en vigor el 25 de diciembre de 2003).

201 (2005) Convenio del Consejo de Europa de Lucha contra la Trata de 3 de mayo de 2005 (entrada en vigor: el 1 de febrero de 2008) para España entró en vigor el 1 de agosto de 2009.

202 Rantsev c. Chipre y Rusia, no. 25965/04. [TEDH, Sección I], 7 de enero de 2010. Párr. 282; ver también: L.E. C. Grecia, no. 71545/12. [TEDH, Sección I], 21 de enero de 2016. Párr. 66.
} 
relevancia tras la reciente opinión del Tribunal de Justicia de la Unión Europea por la que se rechaza la adhesión de la Unión Europea al $\mathrm{CEDH}^{203}$, abriendo así la distancia entre el sistema de protección de los derechos humanos bajo la CDFUE de la UE y el CEDH del CdE. En este sentido, será de especial interés la manera en la que evolucione la doctrina Bosphorus, por la que el TEDH asume la presunción de que cuando un Estado miembro actúa en cumplimiento de sus obligaciones por su pertenencia a otra organización internacional que ofrece una cobertura de los derechos fundamentales equivalente a la del CEDH (véase la UE), cumple también con este ${ }^{204}$.

Una vez delimitado el concepto de trata, el TEDH pasó a analizar las obligaciones positivas tanto de Chipre como de Rusia. EI TEDH consideró que Chipre había vulnerado el artículo 4 del CEDH en tres aspectos. Por un lado, el TEDH afirmó que si bien la legislación chipriota prohibía de forma adecuada la trata y la explotación sexual ${ }^{205}$, el marco administrativo, en especial el régimen del visado de artista, no concedió a Rantseva una protección práctica y efectiva contra la trata de seres humanos y la explotación ${ }^{206}$. Además, a pesar de que las circunstancias permitían albergar la sospecha de que la artista rusa estaba en un riesgo real de ser objeto de trata, Chipre no adoptó las medidas protectoras adecuadas. En último lugar, el TEDH estimó que Chipre tampoco atendió a su obligación de llevar a cabo una investigación eficiente sobre las acusaciones de trata.

En cuanto a Rusia, el TEDH apreció que, para que haya una violación de las obligaciones positivas de protección del artículo 4 del $\mathrm{CEDH}$, "debe demostrarse que las autoridades del Estado conocían, o debían haber conocido, circunstancias que permitieran albergar una sospecha plausible de que un individuo identificado se había encontrado, o se encontraba, en un riesgo real e inminente de ser objeto de trata o explotación" ${ }^{207}$. En este caso, el TEDH entendió que tales circunstancias no habían ocurrido ${ }^{208}$. No obstante, el TEDH sí que estimó que Rusia no respetó su obligación procesal de investigar la denuncia de trata de seres

203 ECJ OPINION 2/13 OF THE COURT (Pleno), 18 de diciembre de 2014. ECLI:EU:C:2014:2454.

${ }^{204}$ Bosphorus Hava Yollari Turizm ve Ticaret Anonim Sirketi c. Irlanda, no. 45036/98. [TEDH, Gran Sala], 30 de junio de 2005, párr. 156; Desde la Opinión 2/13 del TJUE, la doctrina Bosphorus no había sido estudiada en profundidad hasta el reciente caso Avontis c. Letonia, no. 17502/07. [TEDH, Gran Sala], 23 de mayo de 2016, párr. 101127. En dicho caso el TEDH confirma el principio de confianza mutua y reafirma la doctrina Bosphorus en el contexto de la aplicación de Reglamento de Bruselas I. No obstante, no se puede concluir que la doctrina Bosphorus sea de aplicación automática en relación con todos los reglamentos europeos. En este sentido, ver la sentencia M.S.S. c. Bélgica y Grecia, no, 30696/09. [TEDH, Gran Sala], 21 de enero de 2011, párr. 338340 sobre la aplicación del Reglamento de Dublín.

205 Rantsev c. Chipre y Rusia, no. 25965/04. [TEDH, Sección I], 7 de enero de 2010. Párr. 290

${ }^{206}$ Ibídem. Párr. 293.

207 Ibídem. Párr. 286.

${ }^{208}$ Ibídem. Párr. 306. 
humanos dado que no llevó a cabo ninguna investigación sobre las circunstancias del reclutamiento de la víctima ${ }^{209}$. En este sentido, el TEDH confirmó que las obligaciones positivas de los Estados no se extinguen en el momento en el que la violación del artículo 4 supera la frontera, sino que la aplicación del CEDH puede tener un alcance extraterritorial siempre y cuando la protección efectiva de sus artículos se encuentre bajo alcance de la jurisdicción de los Estados parte.

El alcance extraterritorial de la prohibición del trabajo forzado, la servidumbre y la esclavitud no solo abarca aquellos casos en los que el país de destino de la trata es un Estado parte del CEDH (o una región sobre la que Estado ejerza jurisdicción territorial $)^{210}$, sino que se puede extender a violaciones que vayan a ocurrir en terceros países. Si bien la aplicación extraterritorial del artículo 4 no está tan desarrollada como la de otros artículos del CEDH (en especial el artículo 3 del $C_{E D H}{ }^{211}$ ), el TEDH ha reconocido que este principio le es igualmente aplicable. En la decisión de inadmisión en el caso V.F. V. France ${ }^{212}$, relativo a una mujer senegalesa que alegaba que si Francia la expulsaba a Senegal caería en manos de traficantes y se vería forzada a prostituirse, el TEDH sostuvo que "la cuestión de la aplicación extraterritorial del artículo 4 de la Convención en su aspecto de sufrimiento podría valorarse, en especial en virtud del carácter intangible y absoluto de esta disposición[, sin] que sea necesario pronunciarse sobre su naturaleza ya que el sufrimiento es, en todo caso, inaceptable"213.

La aplicación extraterritorial del artículo 4 del CEDH está ligada íntimamente a la protección internacional frente al refoulement que ofrece el asilo y la protección subsidiaria. En este sentido, el TEDH archivó los asuntos L.R. C. Reino Unido ${ }^{214}$ y O.G.O C. Reino Unido ${ }^{215}$ en los que los demandantes alegaban que si les expulsaban a sus países de origen (Albania y Nigeria, respectivamente) habría un riesgo real de ser reclutadas por redes de trata, cuando les fueron concedidos sendos estatutos de refugiadas. Cabe destacar que, en los casos en los que la inadmisión o denegación de la solicitud de protección internacional lleva aparejada la expulsión del territorio de los países parte del CEDH y su ejecución supusiera un riego sobre la persona de ser sometida a trabajos forzados, servidumbre o esclavitud, la aplicación de las medidas

${ }^{209}$ Ibídem. Párr. 309.

210 Ver: Bankovic y Otros c. Bélgica y otros 16 Estados parte (decisión), no. 52207/99. [TEDH, Gran Sala], 21 de diciembre de 2001.

211 Ver, inter alia: Soering c. Reino Unido, no. 14038/88. [TEDH, Plenario] 7 de julio de 1989; Chahal c. Reino Unido, no. 22414/93. [TEDH, Gran Sala] 15 de noviembre de 1996; D. c. Reino Unido, no. 30240/96 [TEDH, Sala], 2 de mayo de 1997.

${ }^{212}$ V.F. c. Francia (decisión), no. 7196/10. [TEDH, Sección V], 29 de noviembre de 2011.

${ }^{213}$ V.F. c. Francia (decisión), no. 7196/10. [TEDH, Sección V], 29 de noviembre de 2011.

" ii. Sur I'obligation positive de I'Etat de prévenir le réenrôlement dans le réseau de prostitution au Nigeria" (traducción propia del francés).

${ }^{214}$ L.R. C. Reino Unido (decisión), no. 49113/09. [TEDH, Sección IV], 14 de junio de 2011.

215 O.G.O c. Reino Unido (decisión), no. 13950/12. [TEDH, Sección IV], 18 de febrero de 2014. 
provisionales en virtud de la Regla 39 del TEDH puede suspender dicha expulsión ${ }^{216}$.

El asunto Idemugia c. Francia ${ }^{217}$, en el que el TEDH aplicó la regla $39^{218}$, resulta de especial relevancia para el presente estudio no solo porque parte de los hechos tuvieron lugar en España, sino también por la controvertida decisión de inadmisión del TEDH. Idemugia vivía en un orfanato cuando, a la edad de 13 años, una mujer nigeriana residente en España le propuso traerla para trabajar en su casa. Mientras se encontraba a Marruecos esperando poder llegar a las Islas Canarias, se queda embarazada. Una vez en Las Palmas, un hombre la viene a buscar y la traslada a Barcelona ${ }^{219}$. En Barcelona le informa de que el viaje había costado $45.000 \$$ y que tenía que prostituirse para devolverle el dinero, bajo la amenaza de quitarle a su hijo y vengarse sobre su familia en Nigeria. Se prostituye durante meses, hasta que cae gravemente enferma y es hospitalizada. Cuando sale del hospital decide huir de la prostitución y su madre en Nigeria comienza a ser amenazada y agredida. El hombre le da un ultimátum para saldar su deuda y le dice que si lleva un paquete de cocaína a Suiza quedará liberada. Injiere varios paquetes de cocaína envueltos con celo y la suben a un tren destino a París. En París es interceptada por la policía y solicita ser devuelta a España para estar con su hija, petición que España rechaza porque su visado era falso. Más tarde, Francia incoa un expediente de expulsión a Nigeria y la demandante, bajo el temor a ser devuelta a su país de origen, formaliza una solicitud de asilo. Su solicitud de asilo es denegada bajo el argumento de que "su partida de Nigeria no podía ser vinculada a ninguno de los motivos de la Convención de Ginebra" 220 y que sus alegaciones eran demasiado vagas. EI TEDH, por su parte, respaldó la opinión de la oficina de asilo francesa alegando que la demandante no había demostrado un riego real de ser maltratada en caso de su retorno ${ }^{221}$. A la luz de los hechos, considero que la decisión de la Oficina de asilo francesa (y del TEDH) constituye un desacierto por los siguientes dos motivos. Primero,

\footnotetext{
${ }^{216}$ ACNUR. Guía relativa a la solicitud de medidas provisionales en virtud de la regla 39 del reglamento del tribunal europeo de Derechos Humanos para personas en necesidad de protección internacional. Documento publicado por la Representación del ACNUR ante las Instituciones Europeas en Estrasburgo. Traducción al español realizada por la Delegación del ACNUR en España. 2a Edición 2013. P. 7 Disponible en http://www.acnur.es/PDF/guia regla39 2013 baja 20130819120506.pdf

217 Idemugia c. Francia (decisión), no. 4125/11. [TEDH, Sección V], 27 de marzo de 2012.

218 Por decisión de 19 de enero de 2011 el TEDH ordena a Francia suspender la expulsión. Un año más tarde, el 27 de marzo de 2012, el TEDH pone fin a la medida cautelar al emitir una decisión de inadmisión del caso.

${ }^{219}$ Nótese el desliz del TEDH al no clasificar los hechos acaecidos en las Islas Canarias dentro del apartado <<Quant aux faits survenus en Espagne>>, que comienza cuando la víctima llega a la Península.

220 Idemugia c. Francia (decisión), no. 4125/11. [TEDH, Sección V], 27 de marzo de 2012 (traducción propia del francés).

${ }^{221}$ Idemugia c. Francia (decisión), no. 4125/11. [TEDH, Sección V], 27 de marzo de 2012 "En droit".
} 
no tiene en cuenta que la persecución por motivos de género, en tanto que "grupo social determinado", se encuentra recogida dentro de la definición del artículo 1.A de la Convención sobre el Estatuto de los Refugiados y la trata de mujeres es una de las representaciones más claras de la persecución por motivos de género ${ }^{222}$. Y, segundo, no valora el principio de unidad familiar y el interés superior del menor, al pretender expulsar a Nigeria a una persona dejando a su hija en España (artículo 8 del $\mathrm{CEDH}$ ). Por tanto, considero que Francia debería haber concedido el estatuto de asilo a la solicitante 0 , al menos, protección subsidiaria $^{223}$ y que el TEDH no debería de haber inadmitido la demanda ya que resulta cuestionable que las autoridades nigerianas pudieran aportar una protección suficiente a la víctima frente a la red de trata que la perseguía y que había agredido a su madre en Nigeria.

Los efectos extraterritoriales del CEDH también pueden activarse por otros factores, como la especial vulnerabilidad de las personas con enfermedades graves. El SIDA es una enfermedad que afecta especialmente a las mujeres trabajadoras del sexo. En un meta análisis llevado a cabo por el World Bank, se calculó que un $11,8 \%$ de las trabajadoras del sexo estaban contagiadas con el virus, índice que se elevaba hasta la cifra de $36,9 \%$ para las mujeres subsaharianas ${ }^{224}$. El TEDH reconoció en el caso $D$ c. Reino Unido que expulsar a una persona con SIDA a San Cristóbal y Nieves hubiera constituido una violación del artículo 3 del CEDH puesto que la falta de un tratamiento accesible le habría abocado a morir en unas condiciones inhumanas ${ }^{225}$. No obstante, el TEDH ha señalado que el mero hecho de haber sido contagiado con el SIDA no te protege frente a la expulsión a un país en vías de desarrollo, sino que tienen que concurrir circunstancias excepcionales. En este sentido, el TEDH consideró en el caso $N$ c. Reino Unido ${ }^{226}$ que el nivel de cobertura sanitaria en Uganda ofrecía unas expectativas de tratamiento suficientes. En relación con el artículo 4 del $\mathrm{CEDH}$, podemos destacar el caso F.A. C. Reino Unido ${ }^{227}$, en el que una ghanesa que contrajo el SIDA

222 Ver: ALTO COMISIONADO DE NACIONES UNIDAS PARA LOS REFUGIADOS: Directrices sobre Protección Internacional: La persecución por motivos de género en el contexto del Artículo 1A(2) de la Convención de 1951 sobre el Estatuto de los Refugiados, y/o su Protocolo de 1967, HCR/GIP/02/01 7 de mayo de 2002; ALTO COMISIONADO DE NACIONES UNIDAS PARA LOS REFUGIADOS: Directrices sobre Protección Internacional no. 9: Solicitudes de la condición de refugiado relacionadas con la orientación sexual y/o la identidad de género en el contexto del artículo $1 \mathrm{~A}$ (2) de la Convención sobre el Estatuto de los Refugiados de 1951 y/o su Protocolo de 1967. HCR/IP/12/09, 23 de octubre 2012.

${ }^{223}$ En junio de 2015, el Tribunal Supremo español en un caso con hechos similares (mujer nigeriana víctima de una red de trata) confirmó la concesión de protección subsidiaria a la víctima. Ver STS 3651/2015 de 21 de julio de 2015

224 KERRIGAN, D; WIRTZ, A; SEMINI, I; N'JIE, N'D; STANCIOLE, A; BUTLER, J; OELRICHS, R; y BEYRER, C.: The Global HIV Epidemics among Sex Workers. $1^{\circ}$ Edición. World Bank: Washington, D.C. 2012, P. 5.

${ }^{225}$ D. c. Reino Unido, no. 30240/96. [TEDH, Sala], 2 de mayo de 1997.

${ }^{226}$ N. c. Reino Unido, no. 26565/05. [TEDH, Gran Sala], 27 de mayo de 2008.

227 F.A. C. Reino Unido, no. 20658/11. [TEDH, Sección IV], 10 de septiembre de 2013. 
en el Reino Unido bajo las manos de sus traficantes alegó que su expulsión a Gana la privaría de un tratamiento médico adecuado y resultaría en un riesgo real volver a caer en manos sus traficantes, lo que supondría un trato contrario al artículo 4 del CEDH. No obstante, el TEDH no valoró la naturaleza del riesgo al que se enfrentaba la demandante y archivó el caso al apreciar que la demandante no había agotado la vía judicial.

El 21 de abril de 2016, la sentencia caso L.E. C. Grecia ${ }^{228}$ devino firme de acuerdo con el artículo 44§2.b) del CEDH tras haber trascurridos tres meses desde la fecha de su sentencia ( 21 de enero de 2016) sin que ninguna de las partes solicitase la remisión del asunto ante la Gran Sala. En ella, el TEDH volvió a condenar a otro Estado por violar los términos del artículo 4 del $\mathrm{CEDH}$ en relación con las obligaciones positivas de los estados de ofrecer una protección práctica y efectiva a las personas en riesgo de caer en manos de la trata de seres humanos. El caso L.E trataba sobre una mujer nigeriana víctima de trata que, tras ver confiscado su pasaporte, fue forzada a prostituirse ${ }^{229}$. Tras informar a las autoridades griegas de su situación tuvo que esperar más de nueve meses para que se le reconociera su estatuto ${ }^{230}$. El TEDH consideró que el hecho de que la víctima se viera obligada a esperar tanto tiempo para obtener una protección efectiva como víctima de trata y a la deficiente investigación de su situación, alcanzó la gravedad suficiente para condenar a Grecia por vulnerar el artículo 4 del CEDH ${ }^{231}$.

El hecho de que Grecia no haya ratificado el Convenio del CdE Contra la Trata hasta el 11 de abril de 2014, a pesar de haberlo firmado el 17 de noviembre de 2005, le ha excluido de la primera ronda de evaluación del Grupo de Expertos sobre la Lucha contra la Trata de Seres Humanos (GRETA). El GRETA es, junto con el Comité de las Partes, uno de los mecanismos de supervisión del Convenio Contra la Trata y su labor de vigilancia y evaluación constituye uno de los pilares de la lucha contra la trata en Europa ${ }^{232}$. España, por el contrario, sí que participó en la primera ronda de evaluación que tuvo lugar de 2010 a 2013. Gracias a los comentarios de GRETA ${ }^{233}$ y del Comité de las Partes ${ }^{234}$, España endureció su lucha contra la trata, corrigiendo algunas de las deficiencias de su sistema que fueron detectadas por los organismos de supervisión e

${ }^{228}$ L.E. c. Grecia, no. 71545/12. [TEDH, Sección I], 21 de enero de 2016.

${ }^{229}$ Ibídem. Párr. 9.

230 Ibídem. Párr. 77.

${ }^{231}$ Ibídem. Párr. 78, 86.

${ }^{232}$ Ver "Capítulo VII - Mecanismo de seguimiento" del Convenio del Consejo de Europa de Lucha contra la Trata.

${ }^{233}$ GRETA. Report concerning the implementation of the Council of Europe Convention on Action against Trafficking in Human Beings by Spain. GRETA(2013)16. Strasbourg, 27 September 2013.

${ }_{234}$ COMMITTEE OF THE PARTIES. Recommendation CP(2013)10 on the implementation of the Council of Europe Convention on Action against Trafficking in Human Beings by Spain. Adopted at the 12th meeting of the Committee of the Parties on 7 October 2013. 
introdujo un Protocolo Marco de protección de las víctimas de trata ${ }^{235}$ que estable un procedimiento para la detección, identificación y derivación de las víctimas, así como favorece la simultánea persecución del delito ${ }^{236}$. De acuerdo con las Reglas de procedimiento de evaluación del Convenio contra la Trata ${ }^{237}$, Grecia deberá recibir el primer cuestionario de evaluación, como tarde, el 1 de agosto de $2016^{238}$. Esta ronda de evaluación será de gran ayuda para que el gobierno griego pueda abordar de forma efectiva la lucha contra la trata y adoptar medidas que prevengan una nueva vulneración de sus obligaciones bajo el artículo 4 del CEDH en el contexto actual en el que Grecia se ve desbordada por la presión migratoria.

Por último, resulta pertinente destacar brevemente dos casos en los que los demandantes no eran las víctimas de la trata sino los propios traficantes. En el caso Kaya c. Alemania ${ }^{239}$, el TEDH consideró que no había habido violación del artículo 8 del $\mathrm{CEDH}$ (derecho a la vida privada y familiar) al expulsar a Turquía a un individuo que había sido condenado, entre otros motivos, por tentativa de un delito de trata y que suponía un riesgo para la sociedad. Asimismo, en el caso Tas c. Bélgica ${ }^{240}$ el TEDH concluyó que alegar una violación del artículo 1 del Protocolo número 1 del CEDH (derecho a la propiedad) en un caso en el que el Estado confiscó parte los bienes de una persona condenada por sendos delitos de trata y explotación. El TEDH alegó que Bélgica, haciendo uso de su margen de apreciación ${ }^{241}$, tenía derecho a interpretar el inciso "de

235 Protocolo Marco de protección de las víctimas de trata. Suscrito por el Gobierno, la Fiscalía General del Estado y el Consejo General del Poder Judicial. Firmado el 28 de octubre de 2011.

${ }^{236}$ Ver SPAIN. Report submitted by the Spanish authorities on measures taken to comply with Committee of the Parties Recommendation CP(2013)10 on the implementation of the Council of Europe Convention on Action against Trafficking in Human Beings. Received on 29 October 2015.

${ }^{237}$ GRETA. Rules of procedure for evaluating implementation of the Council of Europe Convention on Action against Trafficking in Human Beings by the parties. Adoptado el 17 de junio de 2009 y enmendado el 21 de noviembre de 2014. THB-GRETA (2014)52.

${ }^{238}$ A tenor del artículo 3, el cuestionario deberá ser remitido al Estado parte a partir de un año desde que la Convenio entra en vigor y, como máximo, hasta los 2 años. El convenio entró en vigor en Grecia el 1 de agosto de 2014 y, por tanto, el plazo se acabará el 1 de agosto de 2016.

${ }^{239}$ Kaya c. Alemania, no. 31753/02. [TEDH, Sección I], 28 de junio de 2007.

240 Tas c. Bélgica, no. 44614/06. [TEDH, Sección II], 30 de octubre de 2006.

${ }^{241}$ Para una defensa del margen de apreciación (aunque sin referirse a él con dicha nomenclatura) ver el Voto particular de Sir. Gerald FITZMAURICE en Golder c. Reino Unido, no. 4451/70. [TEDH, Plenario], 21 de febrero de 1975, (FITZMAURICE, G. dissenting). Citado en WHITE, R. \& OVEY, C. The European Convention on Human Rights. OUP: Oxford $20105^{\circ}$ ed, P. 79, 96; Para un ejemplo reciente de la aplicación del margen de apreciación en relación con el artículo 4 del CEDH ver el caso Meier c. Suiza (2016) en el que el TEDH concluyó que dado que en los países europeos no había consenso sobre la edad de jubilación de los reclusos, los Estados gozaban de cierto margen de apreciación al respecto. Meier c. Suiza, no. 10109/14. [TEDH, Sección III], 9 de febrero de 2016. Ver también: Graziani-Weiss c. Austria, no. 31950/06. [TEDH, Sección II], 18 de octubre de 2011, párr.57; Zarb Adami c. Malta, no. 17209/02. [TEDH, 
acuerdo con el interés general" de dicho artículo para confiscar los bienes del demandante en el marco de la lucha contra el crimen y la trata de seres humanos ${ }^{242}$. Dicho lo cual, no hay que olvidar que, como bien señaló el TEDH en el caso Chahal c. Reino Unido, ni la lucha contra el terrorismo (o, mutatis mutandis, contra la trata) ni el potencial riesgo para la sociedad que pueda constituir un individuo (o, mutatis mutandis, traficante) puede justificar que los Estados vulneren sus obligaciones absolutas bajo el CEDH, ya que el respeto de aquellas constituye la base de las sociedades democráticas ${ }^{243}$.

\subsection{3.- Sector sanitario}

En esta sección se analizará el alcance del artículo 4 del CEDH en relación con el sector sanitario. En términos generales, los trabajadores en el ámbito sanitario se agrupan dentro de la categoría de profesionales liberales ya que en su actividad impera el aporte intelectual, el conocimiento y la técnica sobre el resultado material de su trabajo. Las profesiones liberales han tenido un gran peso en la jurisprudencia del TEDH sobre el artículo 4 del CEDH. El número de profesionales liberales que han conseguido llegar hasta el TEDH alegando ser víctimas de violaciones del artículo 4 del CEDH es, a todas luces, desproporcionado al ponerlo en relación con el insignificante porcentaje que representan del total de víctimas de trabajo forzado en el los Estados parte del CEDH.

La Comisión Europea de los Derechos Humanos ${ }^{244}$ tuvo que estudiar el alcance de los apartados $4 \S 2$ y $4 \S 3$.d) del CEDH en el caso Iversen $c$. Noruega ${ }^{245}$. El caso Iversen trata sobre un dentista que se quejaba de una ley noruega por la que se obligaba a todo dentista a trabajar durante un periodo de hasta dos años en el servicio sanitario público. El demandante fue destinado al distrito Moskenes en el norte de Noruega. Tras un año de servicio, decidió abandonar su puesto, decisión por la que fue sancionado. El caso fue inadmitido por una mayoría de seis votos a cuatro ${ }^{246}$. Sin

Sección IV], 20 de junio de 2006, párr. 74; Chitos c. Grecia, no. 51637/12. [TEDH, Sección I] 04 de junio de 2015, párr. 94.

242 Kaya c. Alemania, no. 31753/02. [TEDH, Sección I], 28 de junio de 2007. "En droit"

243 Chahal c. Reino Unido, no. 22414/93. [TEDH, Gran Sala] 15 de noviembre de 1996, párr. 79.

244 Hasta la entrada en vigor del Protocolo n. 11 del CEDH, los individuos no tenían acceso directo al TEDH, sino que tenían que acudir primero ante la Comisión Europea de los Derechos Humanos quien, si lo consideraba oportuno, elevaba el caso ante el TEDH.

245 Iversen c. Noruega (decisión), no. 1468/62. [Comisión Europea de Derechos Humanos], 17 de diciembre de 1963, Yearbook 6. Citado en WHITE, R. \& OVEY, C. The European Convention on Human Rights. OUP: Oxford $20105^{\circ}$ ed, pág 199-201.

${ }^{246}$ WHITE y OVEY señalan que "es difícil separarse de la conclusión de que la decisión de la Comisión de inadmitir la demanda se vio influenciada por consideraciones políticas, El caso había causado una considerable controversia en Noruega y la decisión coincidió con una decisión del estado demandado de renovar su declaración aceptando la competencia de la Comisión bajo el antiguo artículo 25 por un período de solo un año." WHITE, R. \& OVEY, C. The European Convention on Human Rights. OUP: Oxford $20105^{\circ}$ ed, P. 201 (traducción propia del inglés). 
embargo, la decisión mayoritaria se encontraba también dividida. Por un lado, cuatro miembros de la mayoría sostuvieron que el trabajo requerido no constituía trabajo forzado en el sentido del artículo $4 \S 2$ ya que para que para que el trabajo sea considerado forzoso u obligatorio, tiene que ser injusto, opresivo o acarrear una dureza innecesaria. El trabajo requerido en el caso Iversen, por el contrario, era remunerado, acorde con la profesión del demandante y no acarreaba ninguna sanción arbitraria o discriminatoria. Por otro lado, los dos miembros restantes de la mayoría mantuvieron que el caso se encontraba dentro del supuesto cubierto en el apartado 4§3.c): "todo servicio exigido cuando alguna emergencia o calamidad amenacen la vida o el bienestar de la comunidad". No obstante, tal y como WHITE y OVEY destacan, esta opinión "está abierta a críticas; ya que parece dudoso que la situación en el norte de noruega pueda ser descrita como 'emergencia' o 'calamidad' en el sentido requerido por el artículo 4§3.c)"247. De hecho, el TEDH en el caso posterior Steindel c. Alemania sobre emergencias en el sector sanitario no recurrió al apartado 4§3.c), sino al 4§3.d).

$\mathrm{El}$ caso Steindel C. Alemania ${ }^{248}$ trata sobre un oftalmólogo que estaba bajo una obligación estatutaria de participar en un servicio emergencia organizado por un organismo público, a pesar de que trabajaba en el sector privado. Dicho servicio de emergencia requería a cada practicante de trabajar - de forma remunerada- 6 días por cada 3 meses de trabajo en labores de emergencia. De no cumplir con la obligación, se enfrentaban a sanciones disciplinarias. EI TEDH consideró que la obligatoriedad del trabajo requerido se encontraba abarcada por el apartado 4§3.d): "todo trabajo o servicio que forme parte de las obligaciones cívicas normales". EI CEDH llegó a dicha conclusión basándose el hecho de que el trabajo requerido no se separaba del ámbito de las actividades profesionales de un médico, la actividad estaba remunerada y la carga no era desproporcionada ${ }^{249}$.

\subsection{4.- Cuerpo de bomberos}

EI TEDH tuvo la oportunidad de estudiar el alcance del artículo 14 del CEDH en relación con el artículo 4§3.d) en el caso Karlheinz Schmidt c. Alemania ${ }^{250}$. En dicho caso, el TEDH tuvo que valorar si la exigencia a los varones de entre 18 y 50 años de contribuir con el cuerpo de bomberos a través del pago de una tasa o participando en el servicio voluntariamente, era conforme con la prohibición de discriminación del artículo 14 del CEDH en relación con el 4§3.d). El artículo 14 que establece que:

\footnotetext{
${ }^{247}$ Ibídem. P. 200 (traducción propia del inglés).

${ }^{248}$ Steindel c. Alemania (decisión), no. 29878/07. [TEDH, Sección V], 14 de septiembre de 2010.

249 Ibídem. "i. Alleged violation of article 4 of the Convention".

${ }^{250}$ Karlheinz Schmidt c. Alemania, no. 13580/88. [TEDH, Sala], 18 de julio de 1994.
} 
"El goce de los derechos y libertades reconocidos en el presente Convenio ha de ser asegurado sin distinción alguna, especialmente por razones de sexo, raza, color, lengua, religión, opiniones políticas u otras, origen nacional o social, pertenencia a una minoría nacional, fortuna, nacimiento o cualquier otra situación."

De acuerdo con el TEDH, el artículo 14 del CEDH establece tres requisitos para que pueda haber un trato diferenciado: (i) que exista una justificación objetiva y razonable, (ii) que persiga un fin justificado y (iii) que haya una relación razonable de proporcionalidad entre los medios empleados y el fin perseguido ${ }^{251}$. Con base en los anteriores criterios, el TEDH consideró (por seis votos contra tres) que Alemania había vulnerado la prohibición de discriminación ya que, "en la imposición de una carga financiera como esta, una diferencia de trato basada en el sexo difícilmente puede estar justificada"252 ya que nunca nadie había sido obligado a ejercer como bombero en Alemania puesto que siempre había habido un número de voluntarios suficiente.

Los tres jueces que votaron en contra justificaron su posición en votos particulares. Podemos distinguir dos líneas argumentales en los votos particulares. Por un lado, los jueces Spielmann y Gotchev justificaron su oposición al voto mayoritario argumentando que, teniendo en cuenta las diferencias físicas entre hombres y mujeres, el trato diferenciado era objetivo y justificado. ${ }^{253}$ Por su parte, el juez Morenilla, en su opinión concurrente, reconoce que puede haber diferencias de trato entre hombres y mujeres basadas en las diferencias biológicas entre los géneros, pero considera que en este caso la discriminación no tenía razones objetivas que la justificasen ${ }^{254}$. Por otro lado, el juez Mifsud Bonnici, en su voto particular discrepante, elabora un argumento más complejo basado en los requisitos de aplicación del artículo 14 del $\mathrm{CEDH}^{255}$. En su opinión, en "un enfoque lógico y jurídicamente correcto", el artículo 14 solo puede aplicarse una vez una provisión sustancial sobre la que el demandante base sus alegaciones haya sido considerada aplicable. Dado que el trabajo requerido al demandante se encontraba expresamente excluido de constituir una violación del artículo $4 \S 2$ al entenderse recogido en el supuesto del artículo 4§3.d), según su opinión, el artículo 14 del CEDH no podía ser aplicado. No obstante, resulta Ilamativo que, a pesar de que Mifsud Bonnici formulara un voto particular en el que defendió la inaplicabilidad del artículo 14, la decisión del TEDH recogió por unanimidad que el artículo 14 en relación con el 4§3.d) era

${ }^{251}$ Karlheinz Schmidt c. Alemania, no. 13580/88. [TEDH, Sala], 18 de julio de 1994. Párr. 24.

${ }^{252}$ Ibídem. Párr. 28 (traducción propia del inglés).

253 Karlheinz Schmidt c. Alemania, no. 13580/88. [TEDH, Sala], 18 de julio de 1994 (SPIELMANN, A y GOTCHEV, D. joint dissenting).

254 Karlheinz Schmidt C. Alemania, no. 13580/88. [TEDH, Sala], 18 de julio de 1994 (MORENILLA, JM. concurring).

255 Karlheinz Schmidt c. Alemania, no. 13580/88. [TEDH, Sala], 18 de julio de 1994 (MIFSUD BONNICI, G. dissenting). 
aplicable ${ }^{256}$, encontrando la discrepancia de votos en la violación del artículo (no en su aplicación) ${ }^{257}$. En la sección siguiente (e. sector de la justicia), se discutirá en profundidad la relación entre el artículo 14 y el $4 \S 3$ en el análisis del caso Zarb Adami c. Malta.

\subsection{5. - Sector de la justicia}

Al igual que en el sector sanitario, la cantidad de casos que han llegado al TEDH sobre presuntas violaciones del artículo 4 del CEDH en relación con la justicia es desproporcionada al compararla con la proporción que representa este sector en la cifra total de víctimas de trabajos forzados, servidumbre y esclavitud en Europa. En el caso del sector de la justica no solo resulta llamativa la cantidad de casos que han sido admitidos, sino también el alto nivel de argumentación de los mismos y la repercusión que han tenido en sentencias posteriores. Estos hechos demuestran lo evidente: las personas con recursos y más aun las que trabajan en el sector de la justicia tienen un mayor acceso al TEDH.

Antes de comenzar el análisis de la jurisprudencia del TEDH sobre el artículo 4 del CEDH en el sector de la justicia, hay que aclarar que, aunque en la versión inglesa del CEDH se utiliza la palabra "labour" -cuyo sentido ordinario apunta al trabajo manual-, hay que entender la expresión "trabajo forzado u obligatorio" en significado más amplio conforme al concepto "travail" -cuyo sentido ordinario recoge tanto el trabajo manual como intelectual-, que aparece en el texto francés de la Convención ${ }^{258}$.

La semejanza de las alegaciones y del razonamiento jurídico del TEDH en los casos Van der Mussele, Bucha y Graziani-Weiss sobre la obligatoriedad de prestar servicios jurídicos impuesta sobre los abogados en ejercicio, invita a realizar un análisis conjunto. El caso Van der Mussele c. Bélgica ${ }^{259}$ trata de un recién licenciado en derecho al que el Estado requirió ofrecer servicios jurídicos a una persona guineana sin recursos, el caso Bucha c. Eslovaquia ${ }^{260}$ de un abogado de oficio al que no se le pagaron las costas por representar a su cliente sin recursos ante el Tribunal Constitucional y el caso Graziani-Weiss c. Austria ${ }^{261}$ de un abogado que tuvo que representar a una persona discapacitada. En los tres casos el TEDH llegó a las siguientes conclusiones: (i) las tareas

\footnotetext{
256 "1. Dit, à I'unanimité, que l'article 14 de la Convention combiné avec l'article 4 par. 3 d) (art. 14+4-3-d) s'applique en I'espèce" Karlheinz Schmidt c. Alemania, no. 13580/88. [TEDH, Sala], 18 de julio de 1994.

257 "2. Dit, par six voix contre trois, que l'article 14 de la Convention combiné avec l'article 4 par. 3 d) (art. 14+4-3-d) a été violé" Karlheinz Schmidt c. Alemania, no. 13580/88. [TEDH, Sala], 18 de julio de 1994.

${ }^{258}$ Van der Mussele c. Bélgica, no. 8919/80. [TEDH, Plenario], 23 de noviembre de 1983. Párr. 33.

259 Ibídem.

${ }^{260}$ Bucha c. Eslovaquia (decisión), no. 43259/07. [TEDH, Sección III], 20 de septiembre de 2011.

${ }^{261}$ Graziani-Weiss c. Austria, no. 31950/06. [TEDH, Sección II], 18 de octubre de 2011.
} 
requeridas corresponden con los trabajos normales de un letrado ${ }^{262}$ (ii) los demandantes habían elegido voluntariamente la carrera de abogado y era previsible que dichas tareas les fueran a ser requeridas como parte de sus obligaciones profesionales ${ }^{263}$; y (iii) la carga de trabajo no era desproporcionada con los beneficios que conlleva poder ejercer la profesión de abogado ${ }^{264}$. Estas conclusiones también son aplicables al caso Mihal c. Eslovaquia ${ }^{265}$ en el que el TEDH consideró que el hecho de que un "oficial de ejecuciones judiciales" ("súdny exekútor" en eslovaco o "judicial enforcement officer" en inglés) ${ }^{266}$ no fuera compensado por los costes de la ejecución de una sentencia no alcanzó la categoría de trabajo forzado.

Por último, cabe destacar el caso Zarb Adami c. Malta ${ }^{267}$, relativo a un farmacéutico maltés que fue convocado para participar como jurado popular un total de cuatro veces entre 1971 y $1997^{268}$. En la cuarta ocasión se ausentó, por lo que fue multado con $240 €^{269}$. El demandante sostuvo ante el TEDH que el sistema de elección del jurado penalizaba a los hombres ya que, en los anteriores cinco años, sólo un 3, 05\% de los miembros del jurado habían sido mujeres, mientras que el 96,95\% restante habían sido hombres, alegando que esto constituía una violación el artículo 14 en relación con el artículo 4§3.d). El TEDH sostuvo que si bien las estadísticas no demuestran por sí mismas una violación del artículo 14 del $\mathrm{CEHD}^{270}$, sí que evidencian que la carga de participar como jurado había sido puesta predominantemente en los hombres ${ }^{271}$ sin que hubiera motivos objetivos razonables que justificasen dicha

\footnotetext{
${ }^{262}$ Van der Mussele c. Bélgica, no. 8919/80. [TEDH, Plenario], 23 de noviembre de 1983, párr. 39; Bucha c. Eslovaquia (decisión), no. 43259/07. [TEDH, Sección III], 20 de septiembre de 2011; párr. 41; Graziani-Weiss c. Austria, no. 31950/06. [TEDH, Sección II], 18 de octubre de 2011, parr. 40.

${ }^{263}$ Van der Mussele c. Bélgica, no. 8919/80. [TEDH, Plenario], 23 de noviembre de 1983, párr. 36; Bucha c. Eslovaquia (decisión), no. 43259/07. [TEDH, Sección III], 20 de septiembre de 2011; párr. 38; Graziani-Weiss c. Austria, no. 31950/06. [TEDH, Sección II], 18 de octubre de 2011, parr. 39.

${ }^{264}$ Van der Mussele c. Bélgica, no. 8919/80. [TEDH, Plenario], 23 de noviembre de 1983, párr. 39; Bucha c. Eslovaquia (decisión), no. 43259/07. [TEDH, Sección III], 20 de septiembre de 2011; párr. 43; Graziani-Weiss c. Austria, no. 31950/06. [TEDH, Sección II], 18 de octubre de 2011, parr. 41.

${ }^{265}$ Mihal c. Eslovaquia (decisión), no. [TEDH, Sección III], 28 de junio de 2011

${ }^{266}$ Ibídem. Párr. 3.

267 Zarb Adami c. Malta, no. 17209/02. [TEDH, Sección IV], 20 de junio de 2006.

268 Ibídem. Párr. 10.

${ }^{269}$ Ibídem. Párr. 11.

${ }^{270}$ Ver el caso Hugh Jordan $v$ Reino Unido en el que el TEDH concluyó que el hecho de que las estadísticas demostrasen un número desproporcionado de muertes y enjuiciamientos entre los católicos, era insuficiente para afirmar que había habido una vulneración del artículo 14 del CEDH. Hugh Jordan v Reino Unido, no. 24746/94. [TEDH, Sección III], 4 de mayo de 2001.

271 Zarb Adami c. Malta, no. 17209/02. [TEDH, Sección IV], 20 de junio de 2006. Parr. 78.
} 
discriminación ${ }^{272}$. Con base en lo anterior, el TEDH concluyó que Malta había violado el artículo 14 en relación con el artículo $4 \S 3 . d)^{273}$.

El caso Zarb Adami (2006) alimentó el debate doctrinal que abrió el juez MIFSUD BONNICI en su voto particular del caso Karlheinz Schmidt c. Alemania (1994) 274 , sobre la naturaleza de los supuestos del apartado $4 \S 3$ y sus implicaciones en la interpretación 14 del CEDH. A la hora de aplicar el artículo 14 del CEDH hay que tener en cuenta que:

"Tal y como el Tribunal ha concluido de forma consistente, el artículo 14 complementa las demás disposiciones sustanciales del CEDH y de sus Protocolos. No tiene existencia independiente ya que solo tiene efecto en relación con 'el disfrute de los derechos y libertades' salvaguardados por aquellas. A pesar de que la aplicación del artículo 14 no presupone la violación de dichas disposiciones -y en esta medida es autónomo- no puede haber lugar a su aplicación salvo que los hechos en cuestión se encuentren dentro del ámbito de uno o más de ellos." 275

La interpretación tradicional del artículo 4 del CEDH dice así:

"El Tribunal es consciente de la estructura específica del artículo 4. El párrafo 3 no está destinado a 'limitar' el ejercicio del derecho garantizado en el párrafo 2, sino a 'delimitar' el contenido de dicho derecho, ya que forma un todo junto con el párrafo 2 e indica que lo que el término 'trabajo forzado u obligatorio' no incluye ('n'est pas consideré comme 'travail forcé ou obligatoire'). Siendo así, el párrafo 3 sirve como ayuda en la interpretación del párrafo 2 ."

De acuerdo con el juez Garlicki, la interpretación tradicional deja los supuestos del párrafo tercero "completamente fuera del alcance del [artículo 4]. Como consecuencia, su regulación no acarrea la relación directa con el 'disfrute de los derechos y libertades' necesaria para activar las garantías de trato igualitario [del artículo 14]" 277 . En este sentido, el juez Garlicki estimó que la consecuencia lógica de la aplicación del enfoque tradicional resulta en una gran dificultad para establecer un vínculo entre el artículo 14 y el 4 del CEDH. De hecho, el juez Casadevall se basó en esta línea argumental para formular su voto particular

\footnotetext{
272 Ibídem. Párr. 82.

273 Ibídem. Párr. 83.

${ }^{274}$ Karlheinz Schmidt c. Alemania, no. 13580/88. [TEDH, Sala], 18 de julio de 1994 (MIFSUD BONNICI, G. dissenting).

275 Ver, inter alia: Dhahbi c. Italia, no. 17120/09. [TEDH, Sección II], 08 de abril de 2014, párr. 39 (traducción propia); Berger-Krall y otros C. Eslovenia, no. 14717/04. [TEDH, Sección V], 12 de junio de 2014, párr. 291; Ruszkowska c. Polonia, no. 6717/08. [TEDH, Sección IV], 1 de julio de 2014, párr. 46; Fabris C. Francia, no. 16574/08. [TEDH, Gran Sala], 07 de febrero de 2013, párr. 47; Cusan y Fazzo c. Italia, no. 77/07. [TEDH, Sección II], 07 de enero de 2014, párr. 54; Kurić y Otros c. Eslovenia, no. 26828/06. [TEDH, Gran Sala], 26 de junio de 2012, párr. 384; Asproftas c. Turquía, no. 16079/90. [TEDH, Sección IV], 27 de mayo de 2010, párr. 48.

276 Ver, inter alia: Stummer c. Austria, no. 37452/02. [TEDH, Gran Sala], 07 de julio de 2011, párr. 120 (traducción propia del inglés).

277 Zarb Adami c. Malta, no. 17209/02. [TEDH, Sección IV], 20 de junio de 2006 (GARLICKI, L. concurring). (traducción propia del inglés).
} 
discrepante 278 . En su lugar, el juez Garlicki propuso sustituir la interpretación tradicional por una interpretación más amplia del artículo 4 por la que "se absorban (incluyan) [los supuestos del párrafo 4] dentro del ámbito de la Convención" ${ }^{279}$. El juez Bratza, recurriendo a la redacción del artículo segundo del Convenio de la OIT no 29 relativo al trabajo forzoso u obligatorio, también abogó por una interpretación más amplia que incluyera el párrafo 3 dentro del alcance del artículo 14, aunque consideró compatible este extremo con la interpretación tradicional del párrafo 3 como delimitador del contenido del párrafo $2^{280}$. De acuerdo con Bratza, considero que "la Convención debe ser interpretada y aplicada en una manera que haga que los derechos sean prácticos y efectivos, no teóricos e ilusorios" ${ }^{281} \mathrm{y}$, por tanto, el artículo 14 ha de ser aplicable. No obstante, conforme con la interpretación de los jueces Garlicki y Casadevall, estimo que el enfoque tradicional y la aplicación del artículo 14 en relación con el artículo $4 \S 3$ son difícilmente reconciliables. Por consiguiente, con arreglo al voto particular del juez Garlicki, considero que el TEDH debe abandonar la interpretación tradicional del artículo 4§3 para dar paso a una interpretación más amplia que sea compatible con los requisitos de aplicación del artículo 14 del $\mathrm{CEDH}$.

\subsection{6.- Restauración}

De acuerdo con el informe del Defensor del Pueblo de 2012 sobre la trata de seres humanos en España, el sector de la alimentación y la hostelería se encuentra especialmente afectado por la explotación laboral, representando un $11,62 \%$ de las víctimas que presentaron un escrito de acusación por estos motivos en el año $2010^{282}$.

En relación con este sector, cabe destacar el caso Stummer $v$. Austria ${ }^{283}$, que trató sobre un recluso que tuvo que trabajar durante varios años en las cocinas y en la panadería de la prisión sin que su trabajo cotizara para su pensión con la Seguridad Social austríaca. El TEDH consideró que no había dudas de que el demandante había realizado en prisión un trabajo al que no se había ofrecido voluntario y bajo la amenaza de una sanción (artículo $4 \S 2$ del CEDH) ${ }^{284}$. No obstante, el TEDH llegó a la conclusión de que dicho trabajo se encontraba

278 Zarb Adami c. Malta, no. 17209/02. [TEDH, Sección IV], 20 de junio de 2006 (CASADEVALL, J. dissenting).

279 Zarb Adami c. Malta, no. 17209/02. [TEDH, Sección IV], 20 de junio de 2006 (GARLICKI, L. concurring). (traducción propia del inglés).

280 Zarb Adami c. Malta, no. 17209/02. [TEDH, Sección IV], 20 de junio de 2006 (BRATZA, N. concurring), párr. 8.

${ }^{281}$ Ibídem, párr. 6 (traducción propia del inglés).

282 DEFENSOR DEL PUEBLO. La trata de seres humanos en España: víctimas invisibles.

Madrid: Defensor del Pueblo, 2012, P. 57. Disponible online en: http://ec.europa.eu/anti-

trafficking/sites/antitrafficking/files/human trafficking in spain invisible victims es 2.p $\frac{\mathrm{df}}{283}$

$\frac{\mathrm{df}}{283}$ Stummer c. Austria, no. 37452/02. [TEDH, Gran Sala], 07 de julio de 2011.

${ }^{284}$ Ibídem. Párr. 125. 
amparado por el artículo 4§3.a): "todo trabajo exigido normalmente a una persona privada de libertad en las condiciones previstas por el artículo 5 del presente Convenio, o durante su libertad condicional". El TEDH observó que las Reglas Europeas de Prisión de 2006 establecían que "los internos trabajadores deben, en la medida de lo posible, estar afiliados al régimen nacional de Seguridad Social." 285 . No obstante, en un ejercicio de análisis de derecho comparado entre los Estados parte del $\mathrm{CEDH}$, el TEDH concluyó que la práctica de los Estados a este respecto no reflejaba unanimidad y que, por tanto, dicha disposición de las Reglas Europeas de Prisión aún no se podía traducir en una obligación bajo el $\mathrm{CEDH}^{286}$. Dicho lo cual, si en el futuro la práctica de los Estados evolucionase en este sentido, el TEDH parece dispuesto a ampliar el alcance del derecho recogido en el artículo $4 \S 2$ para incluir en él la obligación de afiliar a los reclusos en un régimen de seguridad social que incluyera pensión de jubilación.

\subsection{7.- Servicio militar}

En esta sección se analizará cómo ha aplicado el TEDH el artículo 4 del CEDH en relación con trabajos de carácter militar. Esta sección resulta de especial importancia ya que se puede apreciar una significativa y positiva evolución en la interpretación del artículo 4 del CEDH desde el caso W., X., Y. y Z. c. Reino Unido (1963) al reciente caso Chitos c. Grecia (2015).

En el caso W., X., Y. y Z. c. Reino Unido ${ }^{287}$ (también llamado "Sailor Boys case"288) cuatro chicos de 15 y 16 años alistados con el consentimiento de sus padres en la marina británica por un periodo de 9 años alegaron ante el TEDH que el Reino Unido había vulnerado el artículo 4 del CEDH al rechazar sus respectivas peticiones de dispensa del servicio militar. Este caso supuso la primera oportunidad para la Comisión Europea de los Derechos Humanos de explorar el alcance del artículo 4§3.b): "No se considera como "trabajo forzado u obligatorio" en el sentido del presente artículo (...) b. todo servicio de carácter militar o, en el caso de objetores de conciencia en los países en que la objeción de conciencia sea reconocida como legítima, cualquier otro servicio sustitutivo del servicio militar obligatorio". La dificultad de aplicar esta provisión al caso concreto recayó sobre la cuestión de si la expresión "todo servicio de carácter militar" había de limitarse al servicio militar obligatorio o si también cubría el alistamiento voluntario en las fuerzas armadas. Para resolver este asunto, la Comisión Europea de los Derechos

${ }^{285}$ COMMITTEE OF MINISTERS, Recommendation No. R (2006) 2 on the European Prison Rules (Adopted by the Committee of Ministers on 11 January 2006 at the 952 nd meeting of the Ministers'Deputies).

286 Stummer c. Austria, no. 37452/02. [TEDH, Gran Sala], 07 de julio de 2011, párr. 132

287 W., X., Y. y Z. c. Reino Unido, nos. 3435/67, 3436/67, 3437/67 y 3438/67 [Comisión Europea de Derechos Humanos, Plenario], 17 de diciembre de 1963.

${ }^{288}$ WHITE, R. \& OVEY, C. The European Convention on Human Rights. OUP: Oxford 2010 50 ed, p. 203. 
Humanos acudió a los travaux préparatoires del CEDH. La Comisión señaló que la redacción del artículo 4 del CEDH se basó en proyectos tempranos del Pacto Internacional de Derechos Civiles y Políticos que, a su vez, se apoyaban en el Convenio de la OIT no 29 relativo al trabajo forzoso u obligatorio. El artículo 2§2.a) del Convenio no 29 de la OIT reduce su alcance a "cualquier trabajo o servicio que se exija en virtud de las leyes sobre el servicio militar obligatorio y que tenga un carácter puramente militar." No obstante, los redactores tanto del Pacto Internacional de Derechos Civiles y Políticos (artículo 8§3.c.i) como del CEDH (artículo 4§3.b) sustituyeron este inciso por la expresión "todo servicio de carácter militar". A pesar de que la Comisión no encontrara en los travaux préparatoires una justificación de dicho cambio, dedujo que no había sido fortuito. Con base en esta apreciación, la Comisión entendió que el apartado b) del párrafo 3 también abarcaba el servicio militar al que se accede de forma voluntaria. Una vez establecido que el servicio militar voluntario quedaba excluido de la prohibición del artículo $4 \S 2$ al estar recogido en el artículo 4§3.a), la Comisión valoró si en el caso concreto el servicio militar había sido voluntario. La Comisión Europea de los Derechos Humanos estimó que el consentimiento de los padres para alistar a sus hijos en el ejército había sido suficiente. Por consiguiente, la Comisión inadmitió la demanda.

Considero que la decisión de inadmitir la demanda fue desacertada por dos motivos. Primero, como White y Ovey señalan, la Comisión no hizo mención al derecho del menor de decidir si quiere continuar con las obligaciones impuestas por sus progenitores una vez alcanzada la mayoría de edad ${ }^{289}$. Dado que el caso data de 1963 y teniendo en cuenta la evolución de los derechos del niño en el derecho internacional, en especial tras la entrada en vigor de la Convención sobre los Derechos del Niño ${ }^{290}$ en 1990, y en el derecho nacional de los Estados parte del CEDH, si los hechos se volviesen a presentar en nuestros días, lo más probable es que el TEDH no hubiese inadmitido la demanda, como en su día lo hizo la Comisión.

Segundo, la Comisión no interpretó de manera correcta el CEDH a la luz de las normas de interpretación de los tratados de los artículos 31 y 32 del Convenio de Viena sobre el Derecho de los Tratados (a continuación, CVDT). Antes de analizar los travaux préparatoires para interpretar el sentido del artículo 4§3.b) del CEDH, la Comisión tenía que haber cuestionado la pertinencia de acudir a esta fuente de interpretación complementaria. El artículo 32 del CVDT únicamente permite acudir a los travaux préparatoires en dos supuestos tasados: "[(i)] para confirmar el sentido resultante de la aplicación del artículo 31, o [(ii)] para determinar el sentido cuando la interpretación dada de conformidad con el artículo 31: a) deje ambiguo u oscuro el sentido; o b) conduzca a un resultado manifiestamente absurdo o irrazonable".

\footnotetext{
${ }^{289}$ WHITE, R. \& OVEY, C. The European Convention on Human Rights. OUP: Oxford 2010 50 ed, p. 203.

${ }^{290}$ Convención sobre los Derechos del Niño (1989, entrada en vigor: 1990).
} 
La Comisión, de forma contraria a las indicaciones del artículo 31 del CVDT, estudió de manera aislada la expresión "todo servicio de carácter militar" sin tener en cuenta el contexto en el que aparecía. Si la expresión se hubiera leído junto con el inciso posterior sobre los "objetores de conciencia" y el "servicio sustitutivo del servicio militar obligatorio", hubiese quedado claro que esta no había de incluir el alistamiento voluntario. Por tanto, resulta injustificado que se caracterizase de "ambiguo u oscuro el sentido" el artículo 4§3.b) del CEDH en los términos del artículo 32 del CVDT. El TEDH, en una sentencia posterior, comparte esta crítica, afirmando que la Comisión "parece basarse únicamente en la primera parte de la frase del apartado b), refiriéndose a 'todo servicio militar'"291 y que "el párrafo 3.b) del artículo 4 ha de ser considerado en su totalidad"292. Asimismo, con base en "el principio general por el que las excepciones a una regla deben ser interpretadas estrictamente [y más aún cuando] las prohibiciones que aparecen en el artículo $4 \S \S 1$ y 2 de la Convención forman parte de su núcleo duro"293, estimo que el artículo $4 \S 3$. b) tiene que ser interpretado de manera restrictiva, ya que una interpretación expansiva por la que se limitase el alcance de dicho derecho humano sería contraria al objeto y fin del CEDH. En dicha sentencia posterior, el TEDH, una vez concluido que el artículo 4§3.b) estaba destinado para cubrir el servicio militar obligatorio, recurrió, de acuerdo con el artículo 32 del CVDT, a los travaux préparatoires, en concreto a la Convención no 29 de la OIT, "para confirmar el sentido resultante de la aplicación del artículo 31". Finalmente, el TEDH, haciendo uso de la doctrina del instrumento vivo, corroboró que dicha interpretación es conforme con las circunstancias presentes al comprobar que el Comité Europeo de Derechos Sociales también diferencia el servicio militar obligatorio de la carrera militar voluntaria a la hora de interpretar el alcance del artículo $1 \S 2$ de la Carta Social Europea ${ }^{294}$.

El año pasado, el TEDH encontró que Grecia había vulnerado el artículo $4 \S 2$ del CEDH en el caso Chitos c. Grecia ${ }^{295}$. El caso Chitos versó sobre un oficial del ejército griego que se vio obligado a pagar una sanción de más de $100.000 €^{296}$ (que finalmente se redujo a $50.000 €$ tras un recurso judicial ${ }^{297}$ ) por querer dejar su cargo antes de que terminara su servicio. EI TEDH reconoció que los estados tienen cierto margen de

291 Chitos c. Grecia, no. 51637/12. [TEDH, Sección I], 04 de junio de 2015, párr. 81 (traducción propia del francés).

${ }^{292}$ Ibídem, párr. 83 (traducción propia del francés).

293 Ibídem, párr. 83 (traducción propia del francés).

294 (1961) Carta Social Europea (entrada en vigor: 26 de febrero de 1965). Nótese que a fecha 21 de marzo de 2016, España aún no ha ratificado la versión posterior revisada de la Carta. (1996) Carta Social Europea Revisada (entrada en vigor: 1 de julio de 1999). Ver firmas y ratificaciones actualizadas: http://www.coe.int/en/web/turin-europeansocial-charter/signature-ratifications

${ }^{295}$ Chitos c. Grecia, no. 51637/12. [TEDH, Sección I], 04 de junio de 2015.

${ }^{296}$ Ibídem, párr. 18

$297 \underline{\text { Ibídem, párr. } 27}$ 
apreciación para determinar las medidas necesarias para evitar la retirada de los miembros de sus fuerzas armadas y más aún cuando el Estado ha invertido en su formación ${ }^{298}$. No obstante, el TEDH concluyó que, al imponer una sanción tan elevada, las autoridades fiscales griegas habían creado una carga desproporcionada contraria al artículo 4§2 del CEDH.

Por último, hay que señalar que la obligatoriedad de realizar servicio militar en terceros países también puede activar el alcance extraterritorial del CEDH. Cabe destacar el asunto D.H. C. Finlandia ${ }^{299}$ en el que un menor no acompañado somalí alegó que, si Finlandia le mandaba de vuelta a Somalia tendría que alistarse en el ejército y esto hubiese supuesto un trato inhumano o degradante (artículo 3 del CEDH). Finalmente, el asunto fue archivado de acuerdo con el artículo 37§1.a) del CEDH cuando Finlandia le concedió el estatuto de protección subsidiaria. El estatuto de protección subsidiaria y el de asilo otorgan al beneficiario una protección suficiente frente al riego de devolución $y$, por tanto, cuando se conceden no cabe acudir al TEDH ya que, como se afirmó en el caso Sisojeva y Otros c. Letonia, "la maquinaria para la protección de los derechos fundamentales establecidos por la Convención es subsidiaria a los sistemas nacionales que salvaguardan los derechos humanos" ${ }^{\prime 300}$.

\subsection{8.- Sector de la investigación}

Algunos economistas agrupan el conjunto de actividades literarias y científicas con un alto contenido intelectual dentro de otro sector económico al que denominan "sector cuaternario". Teóricamente, es posible que el trabajo forzado u obligatorio tenga lugar en este sector. Asimismo, también es posible encontrar casos de servidumbre o esclavitud en el sector de la investigación. Estos casos, poco frecuentes, se pueden producir, por ejemplo, en el contexto de científicos captados por grupos armados.

Dada la rareza de que estas actividades puedan dar pie a alguna vulneración del artículo 4 del CEDH, no es de extrañar que el TEDH aún no hay encontrado a ningún Estado culpable de haber violado sus términos. El único caso relevante que, en cierta manera, está vinculado con el sector de la investigación es el asunto Talmon c. Los Países Bajos $^{301}$. En Talmon, el demandante defendió que solo estaba dispuesto a trabajar como un "investigador independiente o un crítico social" y que Bélgica no tenía derecho a reducirle la prestación de desempleo por rechazar ofertas de empleo que "no eran adecuadas" para él ${ }^{302}$. Como era de esperar, la Comisión Europea de los Derechos Humanos consideró el

\footnotetext{
${ }^{298}$ Ibídem, párr. 94

299 D.H. C. Finlandia, no. 30815/09. [TEDH, Sección IV], 28 de junio de 2011.

300 Sisojeva y Otros c. Letonia, no. 60654/00. [TEDH, Gran Sala], 15 de enero de 2007, párr. 90.

301 Talmon c. Los Países Bajos (decisión), no. 30300/96. [Comisión Europea de los Derechos Humanos], 26 de febrero de 1997.

302 Ibídem. "The facts: A. The particular circumstances of the case".
} 
caso no suponía ninguna violación del artículo 4 del CEDH y que la demanda estaba manifiestamente infundada ${ }^{303}$.

\section{4.- CONCLUSIONES}

Este artículo ha analizado la jurisprudencia del TEDH de acuerdo con los tres sectores económicos: sector primario, sector secundario y sector terciario.

Gracias a este análisis sectorial se ha podido comprobar la primera de las hipótesis iniciales: "el alcance efectivo del artículo 4 del CEDH varía considerablemente en cada sector económico sin que exista correlación entre el nivel de desarrollo de la jurisprudencia del TEDH y los sectores en los que hay más víctimas de trabajo forzado u obligatorio, servidumbre y esclavitud". Esta observación es evidente al comprobar que la jurisprudencia del TEDH del artículo 4 del CEDH está considerablemente más avanzada en asuntos relacionados con la justicia o la medicina que en cuestiones relativas al sector primario y secundario. No obstante, en el ámbito del trabajo doméstico y del sexo, el número y la importancia de las sentencias del TEDH guarda más relación con la magnitud del problema, abarcando (con la excepción del caso Chitos c. Grecia) la totalidad de las sentencias condenatorias (Siliadin c. Francia, Rantsev c. Chipre y Rusia, C.N. c. Reino Unido, C.N. y V. c. Francia y L.E. c. Grecia).

En cuanto a la segunda hipótesis, "el reducido número de casos en relación con el artículo 4 del CEDH ha impedido al TEDH determinar el alcance efectivo de sus disposiciones", se ha confirmado en parte. Aún queda por determinar el alcance de varios elementos importantes del artículo 4 del CEDH. En particular, el TEDH todavía no ha tenido la oportunidad de explorar el alcance de la prohibición de la esclavitud (artículo 4§1) y de la prohibición del trabajo forzado en relación con trabajos realizados en libertad provisional (artículo 4§3.a)), la situación de los objetores de conciencia (artículo 4§3.b)), el trabajo sustitutorio del servicio militar obligatorio (artículo 4§3.b)) y el servicio exigido cuando alguna emergencia o calamidad amenaza la vida o el bienestar de la comunidad (artículo 4§3.c)). No obstaste, se ha podido comprobar que la jurisprudencia del TEDH en relación -directa o indirecta- con el artículo 4 del CEDH es mucho más extensa de lo que pueda aparentar el reducido número de sentencias condenatorias. De hecho, con la excepción de los elementos anteriormente señalados, el TEDH ha definido con relativa profundidad el alcance del resto de los elementos del artículo 4 del CEDH.

Asimismo, este artículo ha identificado ciertas tendencias positivas, entre las que se encuentran: el uso de la doctrina del instrumento vivo para abarcar la servidumbre doméstica dentro del alcance del artículo $4 \S 1$ (ver Siliadin c. Francia), la inclusión expresa de la trata de seres humanos dentro de las prácticas prohibidas bajo el artículo 4 (ver Ranstev c. Chipre y Rusia), la interpretación del concepto "amenaza de una sanción" en el contexto de las sanciones en materia de extranjería (ver Siliadin $c$.

${ }^{303}$ Ibídem. "The law" párr. 1. 
Francia y C.N. y $V$ C. Francia) y la exclusión de la carrera militar voluntaria fuera del alcance del apartado 4§3.b) (ver Chitos c. Grecia en comparación con W., X., Y. y Z. c. Reino Unido).

No obstante, también se han señalado algunas tendencias negativas. En especial, se ha destacado la incompatibilidad de la interpretación tradicional del artículo 4 con los requisitos de aplicación del artículo 14 del CEDH. Para poder superar este impedimento, se ha propuesto adoptar un enfoque más amplio de la relación entre los párrafos 2 y 3 del artículo 4 del CEDH de acuerdo con el voto particular del juez Garlicki en el caso Zarb Adami c. Malta.

Por último, resulta conveniente destacar el factor económico del trabajo forzado, la servidumbre y la esclavitud. A lo largo del documento se ha ido indicando, en la medida de lo posible, el volumen de beneficios que generan estas prácticas en cada sector. Las dimensiones de estas cifras indican que la solución a este problema no vendrá de la mano de ámbito jurídico, sino que la única forma efectiva de erradicarlo es a través de un enfoque social, económico y, en última instancia, legal. Los altos beneficios que generan evidencian una realidad ineludible: la sociedad está dispuesta a pagar por los productos y servicios que se obtienen de estas prácticas. Hasta que no se entienda que el flujo de capital que llega a las manos de los explotadores se debe de entender desde el modelo económico de la curva de la oferta y la demanda, no se podrá alcanzar nunca una solución duradera. Por mucho que se prohíba la prostitución, si existe demanda, alguien ${ }^{304}$ se encargará de que haya oferta. Por muchas vallas que Europa levante, si existe demanda, alguien se encargará de buscar nuevas vías de entrada. Por mucho que Europa pretenda prohibir a los inmigrantes irregulares trabajar, si existe demanda, alguien se encargará de ofrecerles un trabajo. Perseguir a ese "alguien" concreto detiene su actividad concreta, pero alguien se encargará de sustituirle. La maquinaria implacable de la economía es ajena a los nombres o negocios concretos, solo entiende de oferta y demanda.

${ }^{304}$ Aliteración intencionada. 